\begin{tabular}{|c|c|c|}
\hline$B B C$ & $a D 1 a s$ & $\begin{array}{l}\text { REVISTA BRASILIIRA DE } \\
\text { GEOGRAFIA FÍSICA }\end{array}$ \\
\hline ISSN:1984-2295 & Homepage:https://periodicos.ufpe.br/revistas/rbgfe & \\
\hline
\end{tabular}

\title{
Cartografia Histórica da Cidade do Rio Grande/RS: Expansão Urbana entre 1737 e 2017
}

\begin{abstract}
Maria Cristina Chaves Pires ${ }^{1}$, Ítalo Seilhe Reis ${ }^{2}$, Luiz Henrique Torres ${ }^{3}$, Eder Leandro Bayer Maier ${ }^{4}$
${ }^{1}$ Mestre em Geografia, Laboratório de Climatologia e Cartografia, Universidade Federal do Rio Grande - FURG. Rio Grande/RS. mcristina.pires@hotmail.com (autor correspondente).²Graduando em Geografia, Laboratório de Climatologia e Cartografia, Universidade Federal do Rio Grande - FURG. Rio Grande/RS. italoseilhe@gmail.com. ${ }^{3}$ Doutor em História, Professor Titular do Instituto de Ciências Humanas e da Informação - ICHI, Universidade Federal do Rio Grande- FURG. Rio Grande/RS.lhtorres@furg.br. ${ }^{4}$ Doutor em Geografia, Professor do Instituto de Ciências Humanas e da Informação - ICHI, Universidade Federal do Rio Grande - FURG. Rio Grande /RS.edermaier@ gmail.com.
\end{abstract}

Artigo submetido em 16/10/2019 e aceito em 31/05/2020

\section{R E S U M O}

Os mapas históricos preservam informações geográficas sobre a ocupação humana, a expansão urbana e as transformações ambientais ao longo da história. Nesta perspectiva, efetuamos a coleta, catalogação, descrição e interpretação de mapas do sítio urbano da cidade do Rio Grande, a fim de investigar a expansão urbana desde a fundação em 1737 até 2017 . No presente estudo foram analisados oito produtos cartográficos representativos da expansão do núcleo central urbano da cidade do Rio Grande, foi utilizado desde documentos cartográficos históricos do século XVIII até as imagens de satélite da atualidade, buscando identificar a área urbana e suas transformações. As análises mostraram uma expansão urbana em função do crescimento demográfico propiciado pelas atividades militar, portuárias e industriais, que provocaram profundas alterações na geomorfologia original do pontal. Adicionalmente, a condição fisiográfica é um dos maiores desafios para a expansão urbana do Rio Grande, novas porções de terrenos continuam sendo incorporados ao urbano através de aterros das áreas inundáveis por particulares, nas margens da Lagoa do Patos e Saco da Mangueira. E os projetos formalizados, oriundos do Poder Público, no passado promoveram as principais mudanças ambientais como, por exemplo, os aterros na área do porto, mas atualmente os projetos utilizam de áreas regularizadas. Favorecendo o adensamento urbano. A expansão urbana da cidade aconteceu em resposta à necessidade de desenvolvimento frente aos diversos ciclos econômicos de sua história, alterando a fisiografia do pontal arenoso para atender as demandas socioeconômicas de cada período.

Palavras-chave: Mapa, Registro Histórico, Expansão Urbana.

\section{Historical Cartography of the City of Rio Grande / RS: Urban Expansion between 1737 and 2017}

\begin{abstract}
A B S T R A C T
Historical maps preserve geographic informations of human occupation, urban sprawling and environmental transformations throughout history. In view of this, was performed a map collection, cataloging, description and interpretation of the urban site of the city of Rio Grande, in order to investigate urban sprawling and environmental transformations since its foundation in 1737 to 2017. In this study, eight cartographic products were analyzed, representative of the Urban Core sprawl in Rio Grande, used from historical cartographic documents of the eighteenth century to the satellite images of today, attempt to identify the urban area and its transformations. The analyzes showed an urban expansion due to the demographic growth provided by military, port and industrial activities, which caused profound changes in the original geomorphology of the cape. In addition, the physiographic condition is one of the major challenges for the urban expansion of Rio Grande, new portions of land continue to be incorporated into the urban through landfills of flooded areas by individuals, on the shores of Patos Lagoon and Saco da Mangueira. In contrast formalized projects from the government have, in the past, promoted greatest environmental modifications, such as landfills in the
\end{abstract}


Port area, but currently, the projects use regularized areas which supports urban densification. The urban sprawl of the city occurred in response to the need for development in the face of the many economic cycles of its history, changing the sandy ape physiography to better serve the socioeconomic demands of each period.

Keywords: Map, Historical Record, Urban Sprawl.

\section{Introdução}

A pesquisa tem como objetivo geral coletar, catalogar, descrever e interpretar os mapas históricos da Cidade do Rio Grande, desde a fundação em 1737 até 2017, a fim de analisar a expansão urbana, mostrando os resultados em mapas da expansão do núcleo urbano da cidade do Rio Grande de 1737 a 2017. Os mapas históricos registram ao longo do tempo as modificações espaciais dos sistemas naturais em um núcleo urbano que cumpriu e cumpre diferentes funções sociais, como por exemplo: uma cidade militar, portuária, comercial e industrial.

A cartografia histórica possibilita uma análise integradora dos documentos cartográficos, das características ambientais e da história a fim de compreender os processos de construção do espaço geográfico (IBGE, 2019). A cidade do Rio Grande tem uma gênese militar no período de disputa territorial entre Portugal e Espanha, sua expansão espacial resultou de novas demandas sociais oriundas da função portuária essencial no comércio no período das charqueadas e no desenvolvimento comercial e industrial do início do século XX. No final deste mesmo século, o êxodo rural e a modernização das industrias aceleraram o processo de expansão urbana, bem como no século XXI a cidade presenciou um aumento da densidade populacional da área urbana em função da implementação do Polo Naval.

A cartografia histórica da cidade do Rio Grande possibilitou uma análise espaço-temporal da expansão urbana compreendendo que o espaço urbano é o somatório das construções históricas e das atuais demandas sociais, sendo que o conhecimento cientifico tem dupla função: descrever a história e analisar os processos que configuraram a formação do espaço urbano. Tendo em vista que o conhecimento pode alicerçar ações de melhorias urbanas ou de projetos de expansão. Adicionalmente, a ocupação humana sempre apresentou seus desafios em função do isolamento geográfico, dos terrenos arenosos e da configuração hidrográfica.

Adotando como hipótese que o processo de expansão urbana da cidade do Rio Grande combina a materialização de projetos de Estado e ocupação espontânea, configurando a transformação dos sistemas ambientais em áreas urbanas e seu grau de interferência na paisagem, utilizando a tecnologia dos diferentes períodos históricos. Em outras palavras, os mapas primitivos mostram que os homens utilizaram sistemas ambientais mais adequados para o assentamento humano, com pequenas transformações realizadas por tração animal ou força de trabalho humano, já a queima de combustíveis fosseis e a mecanização possibilitaram a subtração de canais de drenagem, marismas, dunas, terraplanagem de uma ilha, lagos e mantos de dispersão eólica.

O primeiro produto cartográfico do Rio Grande está associado a navegação na Barra do Rio Grande, documentada em 1532 quando foi descoberta por Pero Lopes de Souza e o chamado Rio Grande de São Pedro foi citado no mapa de Gaspar Viegas em 1534 (Biblioteca Nacional, 2019).

A fundação da Colônia de Sacramento em 1680, às margens do Rio da Prata, aumentou a expansão do domínio português para o sul do continente americano. O território que se estendia do Rio da Prata à Capitania de São Paulo interessava a administração da colônia, que pretendia explorar o potencial econômico da região. Começavam a se desenvolver os argumentos que definiram a fisionomia da região e as motivações históricas para o surgimento de localidades. Neste contexto, com a intervenção do poder público português, acontece a fundação em 1737 do Presídio e Comandância Militar do Rio Grande de São Pedro (Torres, 2015).

A fundação do Presídio e Comandância Militar do Rio Grande de São Pedro (atual cidade do Rio Grande - RS) ocorre dentro de uma conjuntura de guerra, é dentro deste contexto geopolítico platino que começou a ocupação do espaço do atual estado do Rio Grande do Sul, com o objetivo de integração com Portugal através da ocupação militar e do povoamento civil (Queiroz, 1987; Torres, 2015).

A natureza inóspita da região trouxe inúmeras dificuldades para seu desenvolvimento, cuja paisagem era dominada por dunas, lençóis de areia, sequência lagunares e de banhados, vegetação pobre e ventos fortes. A vila do Rio Grande (desde 1751) que nasceu com papel militar e geopolítico, decorrente de sua situação 
geográfica, viu seu desenvolvimento acontecer através da posição comercial do porto por onde escoava toda a produção da Capitania no século XIX. Graças ao comércio e ao porto, Rio Grande passou por profundas transformações, ao longo dos anos a cidade portuária passou por ciclos comerciais e industriais e o pontal precisou ser adequado a necessidade de urbanização exigida pelo desenvolvimento. A partir dessa premissa foram executadas diversas alterações no meio físico, através de aterros, nivelamentos, drenagem canalizada e superficial (impermeabilização do solo).

A configuração hidrográfica ao mesmo tempo que é um limitante, é uma característica importante para implementação de atividades portuárias de grandes embarcações. Exemplo disso foi a construção do Super Porto na segunda metade do século XX e a implementação do Polo Naval no início do século XXI, havendo relações com a cidade no processo de expansão e adensamento.

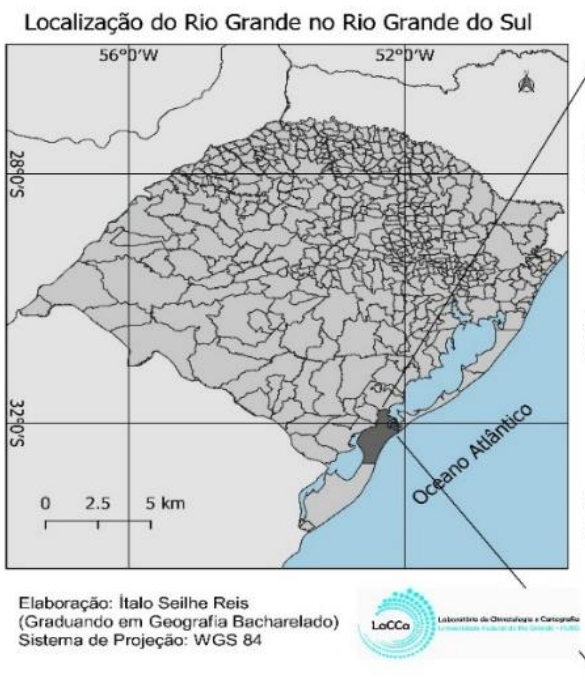

\section{Material e métodos}

A metodologia visa integrar diferentes fontes de informações geográficas para mapear a expansão urbana e as mudanças ambientais da cidade do Rio Grande. Nesse contexto, os mapas históricos, desde os mais rudimentares da época da colonização até os modernos mapas digitais da atualidade, são as principais fontes de informações.

Foram usadas informações da cartografia histórica da gênese e expansão da cidade oriundas dos registros cartográficos, em especial, pelas feições permanentes que caracterizam a história da cidade, porque apesar de sofrerem alterações em sua estrutura permaneceram em seus locais de origem.

\section{Área de estudo:}

Os limites da área de estudo (área urbana do município do Rio Grande) são definidos pelo Porto Velho e o Porto Novo, Bairro Parque Residencial São Pedro, Saco da Mangueira e Canal do Rio Grande.

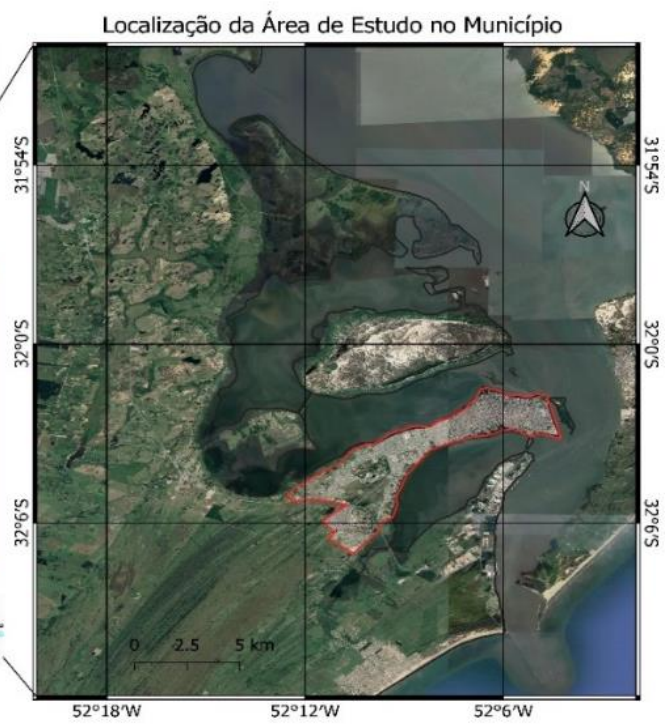

Figura 1. Localização da área de estudo. Com identificação do município do Rio Grande (esquerda) no Estado do Rio Grande do Sul e uma imagem da cidade do Rio Grande (direita) obtida no Google Earth Pro com sobreposição do limite do município.

\section{Dados}

Foram selecionados oito produtos cartográficos da cidade do Rio Grande - RS no período entre 1737 e 2017 (Tabela 1), obtidos no acervo da Biblioteca Rio-Grandense e no acervo pessoal de Fortunato Pimentel. Para representação cartográfica contemporânea utilizamos imagem de satélite do Google Earth Pro, datada de oito de junho de 2017.

Adicionalmente, foram utilizadas imagens complementares para melhor compreensão dos oito mapas citados acima (Tabela 2). Estas imagens são aquarela e fotografias, croquis e mapas históricos em diferentes escalas cartográficas. Os mapas auxiliares são do século XVIII, XIX e XX e forneceram informações adicionais a urbanização, arruamento e outras feições permanentes como, por exemplo, a aquarela de Jean Debret fornece informações sobre a paisagem do porto velho no século XIX. Já as fotografias aéreas são da década de 1940 e de 1964, e foram fornecidas pela Agência da Lagoa Mirim. Para maior detalhamento das 
informações do século $\mathrm{XX}$ foram utilizadas fotografias do Mapa Urbano Base (MUB) na escala 1:5000, fornecidas pela Prefeitura Municipal do Rio Grande, obtidas com máquina digital NIKON Coolpix, modelo P510.

\section{Técnicas de Análise}

No mapeamento da expansão urbana foram utilizados os registros cartográficos, independente de seus usos como, por exemplo, os vazios urbanos. De acordo com Corrêa (2004) os vazios podem ser resultantes dos diferentes usos da terra, reflexos de ações passadas que deixaram marcas nas formas espaciais do presente, o que parece ser o caso predominante no sítio urbano de Rio Grande, como no caso dos terrenos da Viação Férrea. Baseados nesta interpretação, não consideramos estas formas espaciais como objetos destacados do contexto urbano.

Ao observar os documentos cartográficos percebe-se feições naturais e antrópicas remanescentes que podem ser utilizados no presente como feições permanentes representativas de outros usos e configuração do urbano. As feições permanentes, segundo Figueiredo (2013), são elementos que resistiram as transformações da cidade ao longo do tempo e servem como marcos espaciais e temporais, visto que apesar de sofrerem alterações estéticas ou estruturais, permanecem no mesmo lugar.

$\mathrm{Na}$ análise dos mapas históricos de 1737 e 1767 foi utilizada a técnica proposta por Cintra (2015) onde a forma de pintar, os estilos e as cores das tintas empregadas no desenho dos mapas também são relevantes, visto que as informações do sistema ambiental contidas nesses documentos foram representadas através do uso desses recursos da representação cartográfica segundo o conjunto de valores e escolhas do próprio autor do mapa. Sendo distinto da atualidade que é indicado o uso de manuais de padronização.

As informações geográficas dos mapas históricos foram vetorizadas sobre a imagem de satélite georreferenciada com erro máximo de 2 pixeis, extraída do Google Earth Pro, do sítio urbano da Cidade do Rio Grande, de oito de junho 2017. Utilizamos a representação vetorial na forma de polígonos, caracterizados por no mínimo três vértices conectados. $\mathrm{O}$ georreferenciamento e a vetorização foram feitos no software QGIS, versão 3.0 e 3.4. As delimitações poligonais foram criadas de acordo com a análise visual do mapa histórico, cada polígono representa a área urbana construída (ruas, quadras, edificações) correspondente a cada documento cartográfico. As análises visuais basearam-se na interpretação das medidas de distâncias, coordenadas geográficas, figuras geométricas, figuras irregulares, texturas, cores e feições permanentes que representavam os aspectos físicos e humanos nos mapas históricos. Sendo que a localização de cada vetor foi definida pela redundância de informações contidas em um ou mais mapas, conforme os parâmetros a cima descritos. Em casos de imprecisão dos limites da expansão urbana foram utilizadas as imagens complementares para aferir a localização dos limites dos polígonos.

Cada polígono foi datado de acordo com o primeiro registro cartográfico da feição para identificar sua criação. E a quantificação $\left(\mathrm{em} \mathrm{km}^{2}\right)$ foi realizada pela subtração, adotando a diferença como expansão urbana. Por final foram elaborados dois mapas temáticos da expansão urbana, onde são mostradas as áreas e a expansão para cada data dos mapas históricos e a datação da expansão urbana do Rio Grande. Em outras palavras, na Figura 2 são mostrados oito mapas onde a expansão urbana é representada pelo polígono vermelho e as áreas urbanas já existentes em cinza. Na Figura 3 a expansão urbana ao longo do tempo é mostrada usando uma variação coroplética onde se ressalta a relação tempo/espaço em um único produto cartográfico.

Tabela 1 - Identificação dos mapas históricos. Com descriminação do ano de publicação, fonte e principais feições nas colunas.

\begin{tabular}{clc}
\hline Ano & Fonte & Principais Feições \\
\hline 1737 & Biblioteca Rio-Grandense & Forte \\
1767 & Biblioteca Rio-Grandense & Vila \\
1829 & Biblioteca Rio-Grandense & Arruamentos \\
1904 & Biblioteca Rio-Grandense & Centro/Bairro/ Cidade Nova \\
1926 & Biblioteca Rio-Grandense & Porto Novo \\
1942 & Acervo Fortunato Pimentel & Ilha da Base/Cedro e Junção
\end{tabular}


Tabela 2 - Principais feições permanentes ordenadas em sequência temporal, identificadas pelo nome, ano e localização.

\begin{tabular}{clc}
\hline Ano & \multicolumn{1}{c}{ Nome } & Localização \\
\hline 1755 & Catedral de São Pedro & Largo Dr. Pio \\
1820 & Geribanda & Praça Tamandaré \\
1827 & Alfandega do Rio Grande & Rua Riachuelo \\
1829 & Arruamentos & Mal. Floriano/Gen. Bacelar/Riachuelo \\
1855 & Cemitério extramuros & Rua 02 de novembro \\
1870 & Hidráulica & Vila Hidráulica \\
1874 & Fábrica Rheingantz & Av. Presidente Vargas
\end{tabular}

\section{Resultados e discussão}

Nos primeiros planisférios da América a cartografia histórica registra uma longa e monótona costa, do que viria a ser o Rio Grande do Sul, representada por três acidentes geográficos, o rio Martin Afonso (atual Chuy), o rio Tramandaí e o Rio Grande (Diedrich e Machado, 2020).

Os mapas do século XVIII mostram que o pontal do Rio Grande apresentava um sistema ambiental formado por dunas, lagoas, canais, arroios, marismas e banhados. A chegada dos portugueses em 1737 foi o marco inicial do urbanismo lusitano no Rio Grande do Sul, o povoamento da área foi uma tarefa difícil, em virtude do terreno inóspito formado por dois compartimentos com pequena diferença altimétrica: a planície inundável e a planície arenosa.

Conforme Copstein (1982) as plantas utilizadas para o estudo da expansão urbana no início da colonização, não apresentam exatidão desejada, apesar disso são fontes de importantes informações para o estudo histórico da urbanização local. A análise dos documentos descritos foi possível dentro da devida contextualização histórica que nos permitiu compreender as necessidades de alteração do espaço urbano do pontal.

A interpretação de cada mapa histórico está relacionada a técnica de elaboração dos mesmos, visto que os primeiros mapas (século XVIII) foram construídos a partir da abstração do terreno, contendo impressões subjetivas e distorções do traçado. Já os mapas atuais ou imagens de satélite possuem um rigor metodológico e técnico que preserva as dimensões, formas e distâncias de forma mais precisa, quando comparados aos mapas dos séculos passados.

Em síntese, a expansão urbana iniciou-se com a chegada do colonizador português em 1737, que usou para assentamento humano as áreas com menor resistências aos deslocamentos para os fortes e livres de alagamento. No decorrer do tempo, os diferentes usos da terra demandaram por espaços urbanos, sendo que a expansão ocorreu inicialmente no eixo Leste-Oeste, restrito a linha de trincheiras e após o século XX a cidade expandiu para sudeste.

Nas Figuras 2 e 3 é possível observar que a atual área urbana é composta por sucessivas expansões oriundas dos ciclos econômicos e demandas de usos da terra. Sendo que a cidade militar e comercial dos séculos XVIII e XIX ocupa a área central. Nos períodos industrial (têxtil e pesqueiro), no final do século XIX e no século XX, a cidade cresce sobre os campos de dunas e marismas na porção central e sudeste do pontal.

O mapa de 1737, de autoria de José da Silva Paes denominado de "Desenho por ideia da Barra e Porto do Rio Grande de São Pedro" revela a localização do porto, o desenho da fortificação no 
estreito, localização da guarda, ancoradouros das embarcações no lado Norte, banhados que cercam a região, o terreno que chamam Mangueira e a Ilha dos Marinheiros. As formas desenhadas no entorno do pontal presumem a existência de árvores ou arbustos maiores, que não se confirmam nos estudos posteriores. As atividades essencialmente militares deste período fomentaram a construção dos fortes Jesus-Maria-José e do Forte do Estreito situado a dois quilômetros e meio do Porto, criando dois núcleos habitacionais.

As primeiras habitações e caminhos foram construídos em áreas de menor resistência aos deslocamentos para os fortes. A utilização de cavalos e bois degradaram a paisagem vegetal primitiva que permitia a fixação da areia eólica, tornando-se um problema para o povoamento devido a intensidade de movimentação das dunas, promovida pelos ventos fortes predominantes na região. Além disso a precariedade de materiais de construção resistentes também favoreceu a dificuldade das edificações (Copstein, 1982).
Segundo Martins (2016) a expansão urbana do Rio Grande sofreu avanços e recuos, não somente pela dificuldade fisiográfica, mas, também pela invasão espanhola no período de 1763 a 1776 resultando na transferência da capital para Viamão/Porto Alegre e não retornar para a Vila do Rio Grande. Nesse contexto o mapa de 1767 é elaborado pelos portugueses para retomada da vila por um ataque marítimo e terrestre.

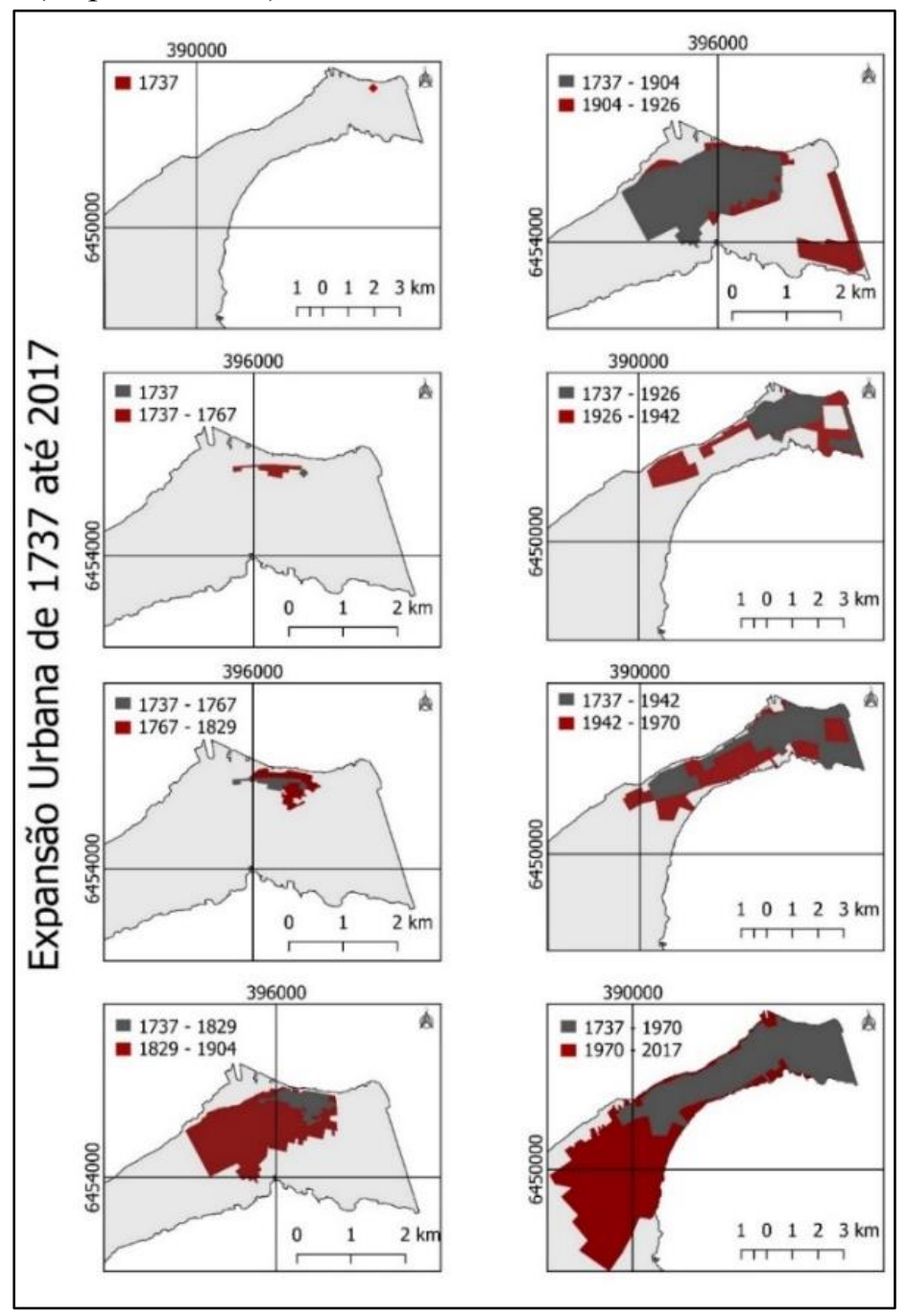

Figura 2. Apresenta a expansão urbana da cidade do Rio Grande de acordo com os mapas selecionados, em cinza a área já urbanizada anteriormente e em vermelho a expansão urbana do período. 


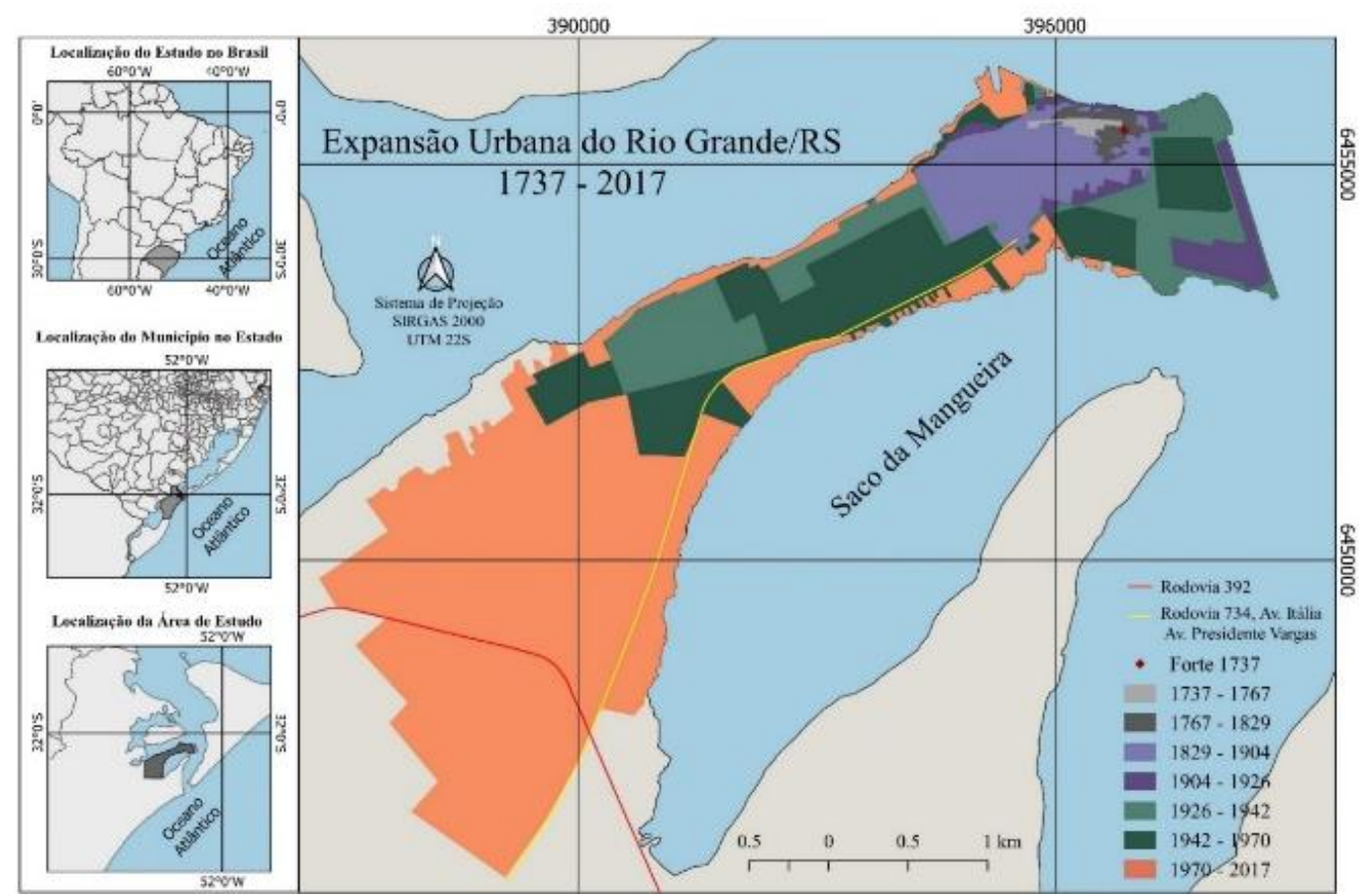

Figura 3. Expansão urbana da cidade do Rio Grande com identificação temporal em cores (1737-2017).

A Planta de Custódio de Sá e Faria (1767), nomeada "Projecto do ataque a cidade do Rio Grande", mostra um casario onde sobressai a Igreja Matriz de São Pedro, a Cadeia, a Casa do Governador, o Pelourinho, uma rua que se iniciava nas proximidades dos banhados do Leste e corria para oeste (Rua Bacelar). Segundo Torres (2018) em 1755, iniciou-se a construção de um cais de pedra nos fundos da Casa do Governador que se situava na Rua Bacelar com Pinto Lima, com esse aterro tem início as edificações que formariam a Rua Marechal Floriano. No sentido Norte-Sul haviam algumas passagens entre as casas denominados "becos".

O documento é um plano de ataque dos portugueses, devido ao domínio espanhol, por este motivo há um detalhamento da localização das baterias, corpo da guarda, armazém de pólvora e por onde as esquadras deveriam navegar.

Neste período houve uma grande decadência do povoado (cidade), ficando reduzido a uma extensa rua com uma igreja. A precariedade das construções favorecia a movimentação das dunas e a paisagem vegetal primitiva teve sua degradação intensificada com a ocupação espanhola, em virtude da grande concentração de bovinos e cavalos necessários para atender as demandas das tropas (Copstein,1982).

A planta demonstra a fisiografia do pontal, que até então parece não ter sofrido grandes alterações, visto que as edificações rudimentares do início do povoamento adaptavam-se as melhores áreas do pontal, que eram entre as marismas e as dunas, com elevação topográfica, livre de inundações e com cobertura de gramíneas que fixava os sedimentos.

A retomada pelos portugueses em 1776 restabelece o povoamento civil e o incremento portuário (Torres, 2015). No final do século XVIII, além da função militar, Rio Grande passa a ter uma importante função comercial. Com a introdução, em 1780, da feitura do charque em escala comercial, o porto do Rio Grande passou a exercer função essencial na comercialização e escoamento do charque e produtos derivados. Também exercia importante papel na chegada de produtos de fora, possibilitando um grande estímulo à economia regional e urbana, tornando-se centro portuário de toda a Capitania, segundo Martins (2016).

É possível reconstruir uma imagem da vila a partir da visão dos viajantes que por aqui passaram em função da intensificação da atividade portuária. Os relatos nos permitem afirmar que nesta fase o desenvolvimento do Rio Grande foi intenso mesmo que as condições adversas do ambiente prevalecessem.

O comerciante inglês John Luccock, em 1809, descreveu a Vila do Rio Grande de São Pedro do Sul, que considerou o maior mercado do Brasil Meridional. Observou ao norte a Ilha dos Marinheiros, ao sul um terreno pantanoso com vegetação parcial, que se elevava próximo ao oceano tornando-se mais seco, ao leste a existência de dunas soltas medindo entre três e quatro metros de altura e para oeste uma região de areais sem vegetação e com leve ondulação. 
Auguste Saint-Hilaire, botânico francês, em viagem de pesquisa ao sul do Brasil em 1820, registra as paisagens encontradas em Rio Grande como terrenos pantanosos que se estendem às margens da Mangueira e dunas de areia fina com esparsa vegetação.

Em 1824 a aquarela do pintor francês JeanBaptiste Debret nos mostra a Vila, em uma rara imagem, mostrando a intensa atividade no porto e retratando a distribuição espacial próximo ao cais, na Rua Riachuelo, área recentemente aterrada.

Ao centro, destacam-se a Matriz de São Pedro e a Capela de São Francisco, a Praça Xavier Ferreira era apenas uma formação arenosa propícia a alagamentos em períodos chuvosos, enquanto que na área da atual Praça Tamandaré, vemos um extenso campo de areais e dunas, que continuava até o horizonte em direção ao atual Bairro Cidade Nova. A rotinas dos moradores, segundo Torres (2018), era marcada pelas dificuldades trazidas pelo deslocamento das dunas móveis que ameaçavam soterrar as edificações com areia, devido a constância dos ventos.

Entretanto, o perfil estético da cidade mudou com o aterramento da atual rua Riachuelo. Segundo Nicolau Dreys a visão dos navegadores que chegavam, era o fundo das casas, mas com o surgimento da nova rua as casas foram construídas de frente para a Lagoa exibindo seu estilo arquitetônico. Segundo Torres (2015), no século XIX, a cidade apresentou considerável expansão da zona urbana, com crescimento em direção oeste, utilizando a Rua Gen. Bacelar e Marechal Floriano como vias principais. Adicionalmente, houve em consequência um adensamento do centro histórico.

O Mapa de 1829 documentou a transformação da cidade em reflexo do período de pujança comercial. O crescimento foi registrado na Planta da Villa de Rio Grande de S. Pedro do Sul, de 1829, tirada por ordem da Câmara Municipal e adaptada de uma planta levantada por Manoel Gonçalves dos Santos. Fica evidenciada a expansão urbana com aterro de marismas e suas delimitações.

Através de convenções são demarcadas as áreas construídas e devolutas de cada quarteirão. Informa o limite do terreno com a frase "Linha dos cômoros que limita o terreno arenozo incapaz de se povoar presentemente" em uma faixa que se inicia ao sul, nas proximidades dos cruzamentos entre as ruas atualmente denominadas de Gen. Vitorino e General Neto; e se dirige para Nordeste até encontrar a atual rua Duque de Caxias. No Oeste quase alcança a frente da Matriz de São Pedro e ao Norte até a rua Bacelar seguindo até as proximidades da atual Visconde de Paranaguá.
Utilizamos as nomenclaturas atuais para efeito de localização, lembrando que algumas ruas atuais ainda não tinham sido projetadas.

As construções urbanas são registradas de uma forma mais compactada desde a rua Riachuelo até a rua Conde de Porto Alegre para o Sul, e entre a rua Zalony e Duprat da Silva para leste. Além das ruas citadas aparecem demarcadas nesta planta, no sentido Norte-Sul: a Rua Marechal Floriano, rua General Bacelar, rua do Hospital (desapareceu), rua República do Líbano e rua Silva Paes. Na direção leste para oeste: rua do Pântano (despareceu), rua Coronel Sampaio, rua Napoleão Laureano e rua Andradas.

As edificações demarcadas são a Matriz de São Pedro, a Capela de São Francisco, a Igreja do Carmo e a Alfandega (nesse momento o prédio ficava de frente para o terreno da praça). Chama a atenção o trapiche junto ao prédio dando ideia do terreno alagadiço e da área que ficava submersa. As praças do Poço e da Alfandega também são registradas.

As ruas estreitas, denominadas "becos", também foram demarcados. Alguns foram precursores das estreitas ruas que existem atualmente no centro da cidade e outros desapareceram: Beco da Genoveva (desapareceu), Beco Francisco Marques, Beco e Trapiche do Joaquim Miz, Beco do Capitão Mor, Beco do Carmo, Beco e Trapiche da Catraia, Beco do Braga, Beco do Barboza, Beco do Lima, Beco do Palácio e Beco do Louzada. Aparecem as Praças do Poço, de São Pedro e da Alfandega, e além da matriz já citada, a antiga Igreja do Carmo e a Capela de São Francisco.

As ruas registradas neste documento de 1829 eram limitadas pelos areais ou pelos banhados/marismas que circundavam o sítio de expansão. Percebemos as primeiras modificações na fisiografia do pontal ao Norte com o surgimento da Rua Riachuelo, pavimentada com aterro procedente da destruição do forte da vila e a nordeste com a área de macega - aterrada por material proveniente das dunas-, bem como o limite urbano projetado (Copstein, 1982).

A cidade, nesta época, apresentava ruas sem calçamento, o que ocasionava dificuldade de trânsito em períodos chuvosos, para carroças e pedestres. $\mathrm{O}$ vento e a areia são personagens constantes na história do Rio Grande e muito dificultaram o processo de urbanização. $O$ combate ao movimento da areia e aos alagamentos tiveram destaque na segunda metade do século XIX, pois era necessário providenciar aterros, nivelamentos e calçamentos das ruas, sendo preciso investimento constante do setor público. Cabe salientar ainda 
que terrenos e edificações da área oeste da cidade foram perdidos pela invasão de dunas móveis. (Salvatori, 1988; Torres, 2018).

No início do século XX, a Planta Geral de Cidade do Rio Grande do Sul de 1904, levantada pelos Engenheiros Antônio C. Chermont e Pedro D. Rache e autorizada pelo Vice- Intendente Municipal Capitão Carlos A. F. De Assumpção, demonstra grandes alterações no espaço urbano, em decorrência da criação de indústrias que propiciaram muitos empregos e da necessidade de terrenos para construção de moradias populares.

A cidade cresceu sensivelmente, de aproximadamente 26 hectares quando da libertação do domínio espanhol, aos 458 hectares até o início do século XX. A infraestrutura urbana sofreu melhorias com o calçamento nas ruas mais centrais, o alargamento de algumas ruas e a expansão urbana em direção sul e oeste (Copstein,1982).

Os dados encontrados sobre população nos informam que no ano de 1900 o número de habitantes do município era de 29.492, sendo que 17.290 viviam na área urbana. Dados iniciais de uma década que marcaria índice tão expressivo de crescimento populacional, que jamais se repetiria.

As dunas que impediam a ocupação urbana desapareceram e ruas no sentido Norte-sul foram abertas até a rua Moron. A leste, surgiu a rua Barroso e a oeste, foram abertas ruas até a Senador Correa. Nota-se arruamentos planejados junto as marismas do Leste até a linha de ferro.

A rua Barroso, devido a sua proximidade com as áreas alagadiças, possuía uma estrutura muito diferente da atual. Segundo Torres (2010) nesta rua existia um canalete (aterrado em 1895) onde canoas e caíques trafegavam trazendo produtos da Ilha do Ladino. Os moradores utilizavam as embarcações para cruzar o macegal lodoso evitando um caminho maior pela ponta da macega.

Para que os pedestres e veículos (carroças e carro de boi) também pudessem circular, foi construída no final da rua Marechal Floriano em direção a macega, uma ponte de madeira em arco, que facilitava a circulação das embarcações. A macega teve ruas abertas a partir da década de 1880, na atual área da Capitania dos Portos. Apesar de não constar nas legendas do mapa de estudo, é possível perceber o desenho da ponte no documento. Nas proximidades da rua Barroso, junto a orla da Lagoa dos Patos, temos as edificações da Estação Marítima, Gasômetro, Capitania do Porto e Moinho Rio-Grandense.

Conforme Copstein (1982) a linha do litoral continuava ganhando espaço sobre as águas. Neste documento percebe-se o aterro entre a
Alfandega e o Mercado, bem como o espaço conquistado para o prédio da Santa Casa e para a Estação Marítima da estrada de ferro. As obras no cais da Boa Vista (Porto Velho) substituíram as estacas de madeira por estruturas de concreto aproximando a rua Riachuelo do perfil atual (Torres, 2015).

Ainda na linha do Canal do Rio Grande, dentro da Cidade Velha aparecem as edificações da Banca do Peixe, da Biblioteca Rio-Grandense, da Fábrica de Conservas Leal Santos, da Fábrica de Biscoitos Leal Santos e a Lavanderia. Ultrapassando a linha de trincheiras pelo litoral estão demarcados a Empresa de Materiais Fecaes, Curtume, Lazareto e o Novo Matadouro, nota-se que estão localizados próximos a uma expressiva área de marismas.

No centro histórico, como resultado da prosperidade trazida pelo comércio, várias edificações são demarcadas, entre elas: Teatro $7 \mathrm{de}$ Setembro, Cine Polytheama, Companhia de Bonde, Hospital do Carmo, Hospital Militar, Beneficência Portuguesa, Asilo Coração de Maria, Igreja da Conceição, Igreja do Salvador e Capela do Bom Fim. Ainda dentro dos limites da Cidade Velha (núcleo central do povoamento), mais ao sul, temos o Asilo de Mendigos e a Fábrica de Tecidos Luso Brasileira. A oeste, junto a antiga linha de trincheiras, temos as edificações do Quartel e da Limpeza Pública.

Neste documento são identificadas seis praças na Cidade Velha: Barão de S. José do Norte (antigo Pelourinho, atrás da Santa Casa), General Telles (atual Xavier Ferreira), 7 de Setembro (antigo Praça do Poço), Vasco da Gama (na rua Barroso, próxima as marismas), Marques do Herval (junto ao Quartel) e Praça Tamandaré.

A Praça Tamandaré é considerada um espaço público rico em histórias e marcante no cotidiano da cidade. Descrita, no mapa de 1829 , como um terreno incapaz de se povoar devido ao terreno arenoso e alagadiço, seus poços viraram local de coleta de água para escravos e populares, teve seu espaço disputado para fins particulares, religiosos e empresariais. Mas manteve-se como espaço público e surge neste mapa como uma área já estruturada e edificada através de aterramento e ajardinamento (Torres, 2016).

A expansão promovida pela prosperidade da cidade, forjou a necessidade da criação de novos espaços de urbanidade e da utilização de áreas além das trincheiras, a chamada cidade extramuros, um crescimento longitudinal que começava a desenhar a futura configuração espacial urbana do pontal. Conforme Martins (2016), para oeste se deu a maior expansão além das trincheiras, com a 
instalação de três grandes estruturas: o Novo Cemitério, o sítio industrial da Rheingantz e a Viação Férrea.

Com a construção do novo cemitério católico (1855) e do cemitério protestante (1856), localizados na atual rua Dois de Novembro, os terrenos extramuros despertaram o interesse da Intendência Municipal que solicitou ao governo imperial a posse desses terrenos devolutos, pois os mesmos passaram a ser vistos como solução dos problemas urbanos da cidade, para localização de fábricas de velas, curtumes e outros estabelecimentos nocivos à saúde pública. Com a confirmação de posse destes terrenos pelo governo imperial a Intendência Municipal disponibilizou a utilização da área (Noguez, 2015).

Uma das primeiras estruturas de expansão urbana extramuros foi a Fábrica Rheigantz, voltada ao manufaturamento de lã ovina, marcou o início da industrialização na cidade do Rio Grande. Fundada em 1873, se instalou na área cedida pela municipalidade em 1884 , em terreno de $143.000 \mathrm{~m}^{2}$ e com área de $43.000 \mathrm{~m}^{2}$, a fábrica e seu sítio industrial iniciaram uma nova extensão da malha urbana. Sítio formado pela planta industrial, pela vila operária, um grupo escolar, casas de mestres e técnicos, jardim de infância, cassino dos mestres, além de vias de deslocamento e casas construídas a oeste da fábrica, após o espaço do cemitério (Martins, 2016).

Surge ao norte dessas estruturas o loteamento Cidade Nova, consequência da entrada da cidade no campo da indústria não-artesanal. A grande quantidade de trabalhadores com baixa remuneração que veio suprir a necessidade de mão de obra ajudou a formar o novo bairro. A ocupação inicialmente também foi influenciada pela localização da Estação Ferroviária e pela proximidade com a cidade.

O bairro foi projetado ao longo da Lagoa dos Patos e paralelo a estrada de ferro, aparecem especificados as quadras e ruas e as boulevards que o cercam. O desenvolvimento do bairro teve importante relação com os complexos fabris existentes em Rio Grande nessa época. A Cidade Nova se caracterizou como um bairro de proprietários e operários inquilinos, a sua abertura duplicou a superfície urbana e por mais de meio século constituiu a principal área de expansão urbana citadina (Copstein,1982).

Outra nova estrutura urbana importante extramuros foi a construção da Estação Central que inaugurou a Estrada de Ferro Rio Grande - Bagé (1884), importante obra de integração econômica com a Campanha Gaúcha. A implementação do parque ferroviário ocupou (presente até os dias atuais, sem desempenhar a mesma função) uma extensa área urbana no limite entre a cidade velha e a cidade nova, junto as antigas trincheiras.

Segundo Martins (2016) com a construção do cemitério, da área industrial da Rheingantz e do complexo ferroviário se inaugurou uma nova fase de expansão em Rio Grande. Na região sudoeste da cidade o mapa nos mostra o reservatório da Companhia Hidráulica Rio-Grandense (1876), estabelecendo a primeira captação e rede de distribuição de água potável, para uma população de pouco mais de 20.000 habitantes. A construção do reservatório era bem distante da zona considerada urbana, a estrutura ainda permanece embora não seja mais utilizada, atualmente transformada em Museu das Águas (Martins, 2016; Torres, 2015).

Outras estruturas aparecem ao sul/sudoeste além da linha de trincheiras: as edificações do Matadouro Velho, Tiro Brasileiro (primeiro Tiro de Guerra no Brasil (1902) que tinha sua linha de tiro na Av. Rheingantz) e o Parque RioGrandense, totalizando 11 quarteirões.

Temos neste documento a demarcação da cidade em projeto: ao norte, entre a Companhia Hidráulica Rio-Grandense e a Lagoa dos Patos, e ao leste no limite entre o reservatório e o bairro Cidade Nova, um novo bairro. Enquanto que quatro novas ruas são projetadas entre a av. Rheingantz e o Saco da Mangueira; também na área da cidade velha a continuação da rua Buarque de Macedo entre a rua Cristóvão Colombo e 15 de Novembro aparece projetada.

No mapa (1904) está registrado uma linha de limite urbano que se desloca do Novo Matadouro até a Junção. A partir deste ponto está traçado o caminho da estrada de ferro paralelo à Estrada dos Carreiros, principal acesso terrestre à cidade. A linha férrea se desloca ao sul do pontal até a Estação Marítima às margens da Lagoa dos Patos. No trajeto junto as marismas da área leste notamos a presença de duas pontes sobre pequenos canais ligados a Lagoa do Ladino e ao Saco da Mangueira.

Segundo Torres (2016) a cidade teve experiência com bondes urbanos, neste período ainda com atração animal, contemporaneamente a linha ferroviária ligando Rio Grande à Bagé. O traçado da Linha de bonde em tráfego registrado no mapa abrange desde o Novo Matadouro, o reservatório, o Parque Rio-Grandense, Avenida Rheingantz, parte do bairro Cidade Nova, centro histórico. Estação Marítima, Praça Vasco da Gama e Capitania do Porto.

Outro traçado da linha de bonde em construção aparece na área projetada ao norte do 
reservatório próximo a Lagoa dos Patos e no limite norte do bairro Cidade Nova, configurando a intenção de complementar os traçados já existentes e buscando abranger a cidade em sua totalidade.

A expansão da zona urbana no início do século XX demonstra o início das grandes modificações que a fisiografia do pontal sofreria, em sua constante adaptação do suporte urbanizável para suprir as necessidades impostas pelo desenvolvimento econômico da cidade, Segundo Copstein (1982): "O rio-grandino viu-se, por isso, obrigado a erguer o chão onde se levantou a sua cidade".

As primeiras décadas do século $\mathrm{XX}$ trouxeram grandes alterações a fisiografia local devido aos projetos de melhoramentos da Barra e a construção do Porto Novo, resultando em grandes áreas aterradas ao leste do centro histórico com material proveniente do aprofundamento do canal de navegação.

Segundo Pandolfo (2018) as mudanças nas cidades são resultados de um processo complexo e simultâneo de produção do espaço, indispensáveis para a construção do projeto urbano.

\section{Na Planta Geral da Cidade do Rio} Grande, de 1926, constata-se a expansão urbana principalmente a leste do centro histórico com a construção do Porto Novo. Conforme Martins (2016) para implantação da obra foi escolhida a área da Ilha do Ladino, extremo leste da cidade, formada por ilhas e alagadiços, com um extenso aterro dividido em duas partes: Terrapleno Oeste junto ao centro histórico e Terrapleno Leste, uma pequena ilha artificial, separada da primeira pelo canal em frente ao novo porto.

Segundo Cunha e Rückert (2019) a utilização desta área para a construção do Porto Novo refletiu os interesses e a necessidade do momento. A Vila que nasceu como ponto de demarcação territorial se tornou um ponto estratégico para o desenvolvimento da economia do estado do Rio Grande do Sul.

Além das obras do Porto Novo se fazia necessário melhorar as condições de navegabilidade da barra devido aos constantes assoreamentos, ideia essa discutida já há algumas décadas, devido à importância estratégica do porto gaúcho. Outro fator importante era a intenção de construir um grande frigorífico com o intuito de modernizar a economia gaúcha e tornar o estado competitivo no mercado mundial neste tipo de manufatura de carne, substituindo o sistema arcaico das charqueadas (Martins, 2016).

O planejamento das obras incluiu além da construção do porto e aterro de toda a área leste da cidade, a remodelagem do Porto Velho e a dragagem do canal de acesso juntamente com a construção de dois grandes braços de pedra (molhes Leste e Oeste) na desembocadura da Lagoa dos Patos. O período de obras pela Companhia Francesa durou de 1908 a 1915 e promoveu modificação generalizada da geomorfologia de todo o segmento leste do pontal.

O material resultado da dragagem dos canais portuários foi utilizado para a construção de terraplenos. O depósito do material dragado sobre o baixio (ou Coroa) do Ladino, resultou no Terrapleno Leste, conhecido como Ilha da Base, (sem registro no mapa em estudo) não apresenta ocupação urbana residencial, pois pertence a Marinha do Brasil que a utiliza para instalações militares.

A área onde foi instalada o Porto Novo, chamada de Terrapleno Oeste, passou pelo mesmo processo ganhando terrenos sobre os aterros na Ilha do Ladino, na Lagoa do Ladino, nos banhados e na ponta da Macega. As extremidades foram ocupadas pelas estruturas portuárias, enquanto as áreas centrais ficaram reservadas para expansão portuária e para um bairro radial planejado pelos franceses e demarcado a oeste do porto até a rua Barroso, mas cuja construção não foi concretizada (Martins, 2016). Ao Sul desta área, identifica-se outro espaço planejado pela Companhia Francesa onde foram construídas as casas verdes e pretas que serviram de residência para os operários vindos da França.

Entre os bairros planejados está demarcada uma área reservada para a Viação Férrea do Rio Grande do Sul. O terreno de instalação da Cia Swift compreendia um total de 23 hectares arrendados junto ao Porto do Rio Grande, em área próxima ao Saco da Mangueira. (Martins, 2016).

As obras projetadas pela Cia Française contemplavam também a remodelagem do Porto Velho, com construção dos armazéns entre a margem da Lagoa dos Patos e a rua Riachuelo (no mapa aparece o registro das cinco novas estruturas que foram realizadas na primeira metade da década de 1920). Outras áreas do pontal continuaram o processo de alterações que já vinham sendo efetuadas. Ao analisar o documento cartográfico percebemos a supressão das marismas a Norte do bairro Cidade Nova próximo a Lagoa dos Patos, bem como o aterro em frente ao prédio da Santa Casa, junto ao Canal do Rio Grande, que permitiu o alongamento da rua Francisco Campello e a instalação de novas edificações.

Ao sul do centro histórico, nas proximidades com a rua Barroso e rua Valporto, 
nota-se o aterramento das marismas e o desaparecimento dos canais que desembocavam na Lagoa do Ladino e no Saco da Mangueira, nesta área surge o planejamento de vários quarteirões. Percebe-se mudanças no final da rua Buarque de Macedo que foi alongada até a rua Domingos de Almeida, bem como o loteamento de quatro quarteirões nesta mesma área.

A partir de 1912 o Departamento de Limpeza da Cidade do Rio Grande, utilizou parte do lixo recolhido das residências para aterrar o prolongamento da rua Mal. Deodoro e Major Carlos Pinto, nos pantanosos trechos em direção à Lagoa dos Patos. Desta forma conseguiram tornar transitáveis e elevar o nível daqueles trechos (Dumith, 2009). Além disso, foram realizadas obras através de três canais, visando facilitar a drenagem da cidade: na Rua Barroso, na Major Carlos Pinto (1.300 metros na antiga trincheira) e outro que faz a ligação entre os dois. (MARTINS, 2004).

A construção dos molhes da barra e de um novo porto atraiu muita mão de obra e novas indústrias, o que implicou na urbanização de novas áreas e consequente modificação geomorfológica onde dunas foram terraplenadas, os banhados e lagoas aterradas e os pequenos arroios foram canalizados.

O espaço aterrado entre o porto e o centro histórico, segundo Martins (2016) configurou um novo padrão de ocupação do sítio urbano formado por favelas com data de ocupação ocorrida a partir de 1920. Os migrantes atraídos pela oferta de emprego acabaram por ocupar uma área periférica próxima aos empreendimentos do Porto Novo e da Swift no lugar destinado para o bairro radial projetado pelos franceses, chamada na época de Vila dos Cedros, atual Bairro Getúlio Vargas. Conforme o autor "a forma de moradia características para as classes de baixa renda, até então vilas operárias ou cortiços, foram substituídas por um conglomerado de casebres de madeira".

Para Martins (2016) as primeiras décadas do século XX foram representativas em termos de expansão urbana da cidade do Rio Grande. A expansão não se deteve apenas ao leste do centro histórico, mas também ocorreu para oeste, além dos limites do bairro Cidade Nova, ao norte da Hidráulica, com a criação de um bairro ortogonal. A estrutura do Jockey Club - Hipódromo Independência, mais a oeste (não aparece no mapa em 1926, mas é um registro relevante), fundado em 1922, dedicado ao lazer e que representou um importante elemento de expansão urbana.
Ao Sul da área do reservatório, o Parque Rio-Grandense passa a ser loteado, vindo a ser ocupado por estruturas beneficentes e residenciais. Estas eram propriedades com maior extensão denominadas chácaras junto ao boulevard Rheingantz, a margem do Saco da Mangueira. As alterações implicam não somente em modificações diretas sobre as feições, mas também nos processos de transporte e deposição dos sedimentos. Como já citado na análise do mapa de 1904, os aterros das margens pantanosas que retinham parte dos sedimentos finos, alteraram a sedimentação e consequentemente o fluxo de sedimentos dentro do estuário, estes passaram a seguir em suspensão até a barra (Telles, 2011).

O período histórico denominado "Era Vargas" influencia a vida política e econômica a partir de 1930 e, em 1937, com a implantação do Estado Novo. Segundo Martins (2016) na área econômica o país buscava desenvolvimento industrial próprio, incentivando a indústria interna e estimulando a união dos mercados nacionais. Como consequência surgiu a concorrência dos grandes centros São Paulo e Rio de Janeiro que passaram a encabeçar a economia e os mercados consumidores, desacelerando as indústrias fabris sul-riograndenses. Outro fator importante é a redução do transporte de cabotagem, durante a Segunda Guerra Mundial, que prejudicou a cidade portuária do Rio Grande.

Entretanto esse período é marcado pela contradição, pois mesmo as empresas do Sul concorrentes da economia do Sudeste, conseguiram sobreviver economicamente devido a Grande Depressão de 1929 e a Segunda Guerra Mundial (1939-1945), pois a produção voltada para exportação continuava em ritmo elevado. As grandes indústrias têxteis do Rio Grande, Rheingantz e Ítalo-Brasileira, bem como o frigorífico Swift mantiveram níveis elevados de produção, mesmo com a diminuição do mercado interno.

A Planta Geral da Cidade do Rio Grande de 1942 levantada pela Diretoria de Obras e Viação da Prefeitura Municipal, demonstra uma área projetada junto ao Canal do Rio Grande, o surgimento de uma área aterrada ao sul do centro histórico junto ao Saco da Mangueira e o registro do Terrapleno Leste. No entanto sua característica mais relevante é a demonstração da continuidade no padrão de crescimento da zona oeste do pontal.

No documento está registrada uma área de expansão urbana projetada junto ao Canal do Rio Grande, numa área extensa que ia do centro histórico até as proximidades do Hipódromo. Está registrado também uma área projetada ao sul, que 
ia do Frigorifico Swift até a Fábrica Rheingantz. Os projetos não foram executados, provavelmente por já existir oferta pelas elites locais de grande quantidade de terra, que não demandavam grandes quantidade de aterro e pela diminuição do ritmo de crescimento fabril nas décadas seguintes (Martins, 2016).

Ocorre a edificação da Refinaria de Petróleo Ipiranga (1937), junto as margens do Saco da Mangueira sobre uma área de terrenos alagadiços, usando aterro com material retirado do próprio estuário. Segundo Dumith et, al. (2008) foi realizado aterro em uma extensa área para viabilizar a construção da planta da refinaria, bem como o estabelecimento de futuros conjuntos residenciais. Não se observa ocupação residencial, na década de 1940, nas margens do Saco da Mangueira compreendidas entre $o$ aterro da refinaria e a Fábrica Rheingantz.

Conforme Martins (2016), a localização inicial da refinaria seria em frente ao Porto Novo e junto à Cia Swift em um terreno de quatro hectares cedido pelo Governo do Estado, mas a necessidade de uma ligação ferroviária com o Porto, acabou inviabilizando o projeto. Uma nova área foi definida ao sul do centro histórico, de 10 a 12 hectares, com fácil ligação com o cais, acesso rodoviário a cidade, água potável e rede elétrica, nas margens do Saco da Mangueira.

Cabe salientar que a implantação da refinaria em Rio Grande deu-se em função da proximidade com a estrutura portuária. É a segunda mais antiga fábrica em funcionamento em Rio Grande (atualmente denominada Refinaria RioGrandense), perde somente para a Fábrica Leal Santos.

Consolidando a tendência de crescimento para oeste, este mapa de 1942 registra o surgimento dos dois primeiros grandes loteamentos, distantes da área central, com proprietários privados. A Vila São Miguel e a Vila Junção que transpõem o limite urbano legal definido anteriormente.

A Vila São Miguel, um loteamento ortogonal com um traçado ao centro, com quatro vias radiais a partir de uma praça central, apresentando 951 lotes distribuídos em 91 quadras. A implantação do loteamento foi planejada numa área após o Hipódromo da Independência. Para Martins (2016) embora a vila apareça no mapa da década de 1940 acredita-se que sua ocupação tenha ocorrido a partir da década seguinte quando seu registro foi efetuado junto à Prefeitura Municipal do Rio Grande.

O outro loteamento projetado foi a Vila Junção, criada em 1942, com 15 quadras, num total de 512 lotes. O nome da vila teve origem na estação de trem que havia no local e chamava-se junção devido à confluência das duas linhas férreas: uma que ia para o Cassino e outra para Pelotas e restante do Estado. As vilas começaram a fazer parte do traçado urbano, aqui identificadas diferentemente do sentido usual (sinônimo de povoado), no sentido de bairro pobre, de periferia, desprovido de estrutura urbana. Apesar de terem situação regularizada junto a Prefeitura Municipal elas carecem de infraestrutura e se localizam em zonas menos valorizadas. Os loteamentos próximos ao centro ou em áreas valorizadas devido à infraestrutura, eram chamados parques ou bairros e não eram denominados vilas (Martins, 2016).

$\mathrm{Na}$ década de 1940, os melhoramentos urbanos continuaram a ser efetivados com o incremento no transporte por ônibus urbano (início em 1939) e a extensão das linhas de bonde. No início da década ocorreu o asfaltamento de 20 quilômetros da estrada que ligava a cidade do Rio Grande à Vila Siqueira (atual Balneário Cassino). Constituiu-se como a primeira estrada asfaltada do Rio Grande do Sul pois antes o trânsito era feito por linha férrea ou estrada de terra. Também ocorreram melhoramentos urbanos, fomentados pela iniciativa privada, ligados ao abastecimento, saneamento, fornecimento de energia elétrica, comunicações e transportes.

A cidade do Rio Grande na década de 1940, segundo Pimentel (1944) era organizada em 10 avenidas, 97 ruas, 44 travessas, 16 largos e praças. Havia mais de 8.000 prédios, 532 destes com mais de um piso. Destes prédios, 4.500 tinham recolhimento de esgoto e 5.500 contavam com abastecimento de água encanada, representando um número elevado de atendimento para a época. Cabe salientar que em termos relativos a cidade não conseguiu mais atingir esses números, no que se refere a rede de esgotos. Conforme Martins (2016) esta configuração do centro e áreas próximas denotava uma concentração de capital de intensa urbanidade.

A expansão urbana se caracterizava por uma espacialização dispersa, pois a cidade possuía vastas áreas como a Hidráulica, no entanto havia semelhança de estrutura no tipo de ocupação. A cidade possuía avenidas e ruas largas, dentro de um padrão ortogonal, que no dizer de Martins (2016) facilitava a contagem de prédios. Com exceção da parte inicial do centro histórico que apresenta até os dias de hoje ruas estreitas e enviesadas e a ocupação do Terrapleno Oeste com ocupação desordenada.

A expansão urbana ocorrida a partir da década de 40 , até a década 70 , será discutido na sequência, baseados na intepretação da Planta da 
Cidade do Rio Grande de 1970 levantada por José M. L. Souza e Antônio C. S. Pereira, publicada no Jornal Rio Grande, que demonstra a consolidação do crescimento da área urbana para oeste do pontal.

Nesse contexto, alguns loteamentos aparecem projetados nas plantas desde a década de 1920, mas a efetiva ocupação ainda demorou, conforme pode ser observado em fotografia aérea de 1947. Nesta fotografia é possível observar o trecho compreendido entre as ruas Domingos de Almeida e a atual Saturnino de Brito, cujos loteamentos já constavam nas plantas urbanas desde a década de 20 e que, no entanto, não estavam efetivamente ocupadas no final da década de 40, mantendo ainda o modelado eólico (Telles, 2011)

Segundo Salvatori (1988) o período de industrialização compreendido entre 1920 e 1950 proporcionou um grande fluxo de migrantes, na maioria operários de baixa renda e pouca instrução, favorecendo o processo de marginalização social. Em 1945 através do Decreto 324/45 foram fixadas zonas de permissão para construção de habitações de madeira na periferia, colocando fim na expansão planejada da cidade.

Os novos loteamentos possuíam ruas mais estreitas e quadras menores, pois era necessário aproveitar o máximo de cada lote, surgem loteamentos enviesados para se adaptar ao lote a ser urbanizado. Este tipo de loteamento ocorreu em toda a cidade, mas a incidência maior foi na parte sudoeste junto a Avenida Itália.

A partir de 1950, com a política governamental de reabertura das importações, as empresas sul-riograndenses sofreram com a concorrência do parque produtivo paulista. As empresas têxteis, o frigorífico e outras empresas instaladas tinham dificuldade na ampliação da produção, mesmo assim verificou-se a continuidade de implantação de parques fabris, embora em ritmo menor. Outros setores fabris vieram a se desenvolver na cidade como: a indústria pesqueira e as indústrias de base (Martins, 2016).

As indústrias de alimentação no setor pesqueiro estavam em desenvolvimento em Rio Grande desde 1889, considerado um dos mais tradicionais setores industriais da cidade, mas foi a partir de 1930 que o setor vivenciou o crescimento no número de empresas e consolidou a cidade no setor de pescados, uma atividade fabril pioneira no país. O espaço urbano ocupado pelas indústrias pesqueiras se deu principalmente junto aos corpos de água, distribuídas ao norte do pontal, próximas as margens da Lagoa dos Patos, onde está localizado o núcleo urbano central.
As décadas de 40/50 se caracterizaram pela grande oferta de terrenos, com as taxas de crescimento populacional superior as médias do estado, a área ocupada dobra. Os índices de urbanização atingem $80 \%$ a partir de 1950 e refletem na expansão do tecido urbano. A criação de novos loteamentos representou o principal marco no espaço urbano da cidade e cabe salientar que a criação de novos lotes urbanos significou a expansão da cidade, mas não gerou ocupação imediata das novas áreas (Salvatori,1988). Para mais informações sobre os loteamentos consulte Martins (2016).

Em 1950 a Prefeitura Municipal buscou regularizar a área onde atualmente situam-se os atuais Bairro Getúlio Vargas e Vila Santa Tereza, ocupações nas imediações do Porto Novo e da Cia Swift, em terrenos que pertenciam ao Governo do Estado, representado pelo Departamento de Portos, Rios e Canais (DEPREC).

Neste período começaram as remoções dos mocambos existentes na Vila dos Cedros (atual Bairro Getúlio Vargas) e Santa Tereza, tendo como principais promotores a Prefeitura Municipal e o Porto Novo. A intenção da Prefeitura era urbanizar o terrapleno Oeste e para isso precisava "limpar" a área, enquanto que o Porto buscava ampliar sua área de atividade.

A oficialização da Vila Santa Tereza aconteceu em 1952, com 20 quadras divididas em 585 lotes. Já o Bairro Getúlio Vargas foi oficializado somente em 1957 com 641 lotes distribuídos em 35 quadras, com uma área de $557.918,00 \mathrm{~m}^{2}$ (Salvatori, 1988; Martins, 2004).

$\mathrm{O}$ registro de loteamentos na zona urbana começa a aumentar a partir 1953 com dois loteamentos registrados, em 1957 com 7 loteamentos, com uma área de 894.304,62 $\mathrm{m}^{2} \mathrm{e}$ 1.945 novos lotes urbanos. Dentre esses loteamentos dois devem ser destacados; a Vila Recreio com 521 lotes distribuídos em 22 quadras e a Vila Santa Rosa com 543 novos lotes, situados distante do centro da cidade e desprovidos de qualquer tipo de infraestrutura (Martins, 2016).

No ano seguinte, em1958, foram oficializados junto a Prefeitura Municipal 14 loteamentos, sendo que nove destes foram em zona urbana contígua com 1.467 novos terrenos, destacando-se a Vila São João com 850 novos lotes, distribuídos em 49 quadras.

Em 1959 houve expressiva expansão com 8 novos loteamentos na zona urbana, dois deles feitos pela própria Prefeitura Municipal, com destaque para o Salgado Filho que devido à localização (próximo ao centro) foi chamado de parque residencial, resultando em terrenos mais 
valorizados, com 440 novos lotes em 19 quadras de área aterrada (Martins, 2016).

A expansão de loteamentos no final da década de 1950 caracteriza-se, segundo Martins (2004) pela proximidade com os locais de trabalho, ou seja, localizavam-se próximo ao Porto, a Cia. Swift e a Refinaria Ipiranga. Esse período é considerado contraditório, pois houve a criação de vários loteamentos em função do crescimento econômico das décadas anteriores, paralelamente ao fechamento de algumas indústrias importantes.

$\mathrm{Na}$ década de 1960 os loteamentos apresentaram uma nova característica: possuíam maior número de lotes e não apresentavam vínculo direto com nenhuma indústria. Em 1964 foi criado o primeiro loteamento do tipo Companhias de Habitação Popular (COHAB) financiado pelo Estado, com 138 casas populares, em área anteriormente pertencente a Hidráulica, a oeste da Cidade Nova e não tão distante do centro da cidade.

Outros dois loteamentos foram o da Cooperativa Habitacional dos Operários de Rio Grande Ltda. (HABICOP), com a construção de 61 lotes e o Parque Residencial Lar Gaúcho com 308 lotes. Estes loteamentos são vizinhos entre si e próximos a Refinaria de Petróleo Ipiranga, financiados pelo Banco Nacional e construídos com o objetivo de reduzir o déficit habitacional.

A população continuou crescendo na década de 1960, apesar da decadência das indústrias fabris e da consequente diminuição dos postos de trabalho. Cabe aqui ressaltar a atuação das empresas pesqueiras responsáveis por parte do dinamismo industrial da cidade nesta fase. No período de 1960 a 1963 chegavam a 17 firmas e além do pescado, algumas trabalhavam com frutas e legumes enlatados. Os anos de 1980 representaram o ápice do setor quando operavam 27 empresas, chegando a empregar 20.000 trabalhadores (Martins, C. 1997).

Em termos de espaço urbano o que ficou registrado, na década de 1960, foi o preenchimento de alguns espaços vazios nos bairros implantados até 1940 , incluindo loteamentos junto aos corpos de água nas margens da cidade e os loteamentos para oeste na direção do balneário Cassino e da Vila da Quinta.

A imagem extraída do Google Earth Pro da Cidade do Rio Grande, datada de 2017 mostra a configuração do pontal entre 1970 e 2017. Para a cidade do Rio Grande a década de 1970 é caracterizada pela Construção do Distrito Industrial e das novas instalações do chamado Superporto dentro do contexto do projeto Corredor de Exportações do Governo Federal.
Segundo Torres (2015) o projeto visava estimular ao máximo as exportações de produtos agrícolas, adaptando-se a uma economia nacional que fortalecia a monocultura da soja como base produtiva. O porto do Rio Grande assumiu papel de protagonismo no escoamento da safra de soja do Rio Grande do Sul com a implantação do Distrito Industrial no amplo espaço portuário. A área junto ao Superporto recebeu a instalação de empresas de fertilizantes e óleo de soja que buscavam reduzir custos com esta localização privilegiada, já que os insumos necessários para produzir eram todos importados.

Conforme Torres (2015) neste período ocorreu a substituição das indústrias de bens nãoduráveis pelas indústrias de bens intermediários. As novas indústrias instaladas diferenciam-se das anteriores, no que se refere a ocupação do espaço, pois as mesmas ocupavam áreas determinadas afastadas do centro urbano, separando os espaços de trabalho, moradia e lazer.

A instalação do complexo portuárioindustrial atraiu um significativo número de migrantes, com a criação de 10.000 mil postos de trabalho na construção civil e vagas de trabalho nas novas indústrias. Junta-se a isso o desenvolvimento da indústria pesqueira, que nas décadas de 1970 e 1980 apresentou seu maior crescimento quanto à criação de empregos e volume transformado de matéria prima (Torres, 2015; Martins, 2016).

Na década de 1980 a expectativa de ocupação dos espaços destinados aos novos empreendimentos não se concretizou, deixando a infraestrutura criada sem plena utilização. Mesmo assim a população atraída pela demanda de empregos na década anterior permaneceu na cidade encorpando a disputa por imóveis na periferia urbana, principalmente nos loteamentos direcionados a população de baixa renda, tipo $\mathrm{COHAB}$, onde a iniciativa privada contava com o auxílio do Sistema Financeiro de Habitação (SFH).

A expansão urbana deste período teve como principal fator a propagação de loteamentos e conjuntos residenciais verticais destinados a trabalhadores e foram oferecidos 3.342 apartamentos distribuídos em 28 condomínios. Já no próximo quinquênio houve uma queda para três conjuntos com 144 unidades. Segundo Martins (2016) isso ocorreu devido ao começo da queda industrial na cidade e a diminuição dos recursos estatais com o fechamento do Banco Nacional de Habitação (BNH), em 1986.

Os primeiros conjuntos na década de 1970 foram construídos próximo ao centro da cidade e as indústrias de pesca. Na década de 1980 percebe-se 
que as construções foram feitas de preferência próxima a Avenida Santos Dumont e Avenida Itália, junto a principal entrada e saída da cidade. Foi edificado próximo ao trevo de acesso da cidade o Residencial Waldemar Duarte, com 800 apartamentos, distante cerca de 12 quilômetros do centro do pontal.

A ocupação do espaço urbano teve contribuição importante com a implantação de duas estruturas: o novo campus da Universidade Federal do Rio Grande - FURG, na década de 1970 e a transferência do Comando do $5^{\circ}$ Distrito Naval de Florianópolis para Rio Grande, em 1983. A criação da nova estrutura da universidade denominada Campus Carreiros, junto ao aeroporto, induziu a expansão da zona urbana à medida que atraiu população para o entorno.

A instalação do $5^{\circ}$ Distrito Naval, junto ao Canal do Rio Grande, nas proximidades do Porto Novo, também contribui para a expansão urbana com a construção e instalação de novos prédios na cidade. O Plano Diretor de Desenvolvimento Integrado em 1986 incorporaria à área urbana do Rio Grande o Balneário Cassino e o Distrito Industrial, bem como alguns bairros que estavam sendo implantados próximo ao trevo de acesso, duplicando com isso a zona urbana. As áreas do Balneário Cassino e Distrito Industrial não fazem parte do objeto deste estudo, mas configuram importantes vetores de expansão urbana.

Nas décadas de 1970 e 1980 houve a construção de três grandes loteamentos, através de financiamento estatal, do tipo COHAB. Em terrenos antes pertencentes a Hidráulica, foi erguido em 1977, o loteamento COHAB II, assim denominado pois já existia outro, com 325 casas de $30 \mathrm{~m}^{2}$, financiadas em 25 anos e que se mostrou insuficiente para a demanda.

Na década de 1980 foram erguidos outros dois conjuntos residenciais. O Parque Marinha do Brasil representou um dos mais importantes empreendimentos imobiliários para a cidade pela dimensão espacial que ocupou. Situado as margens da BR 392, portanto distante do centro da cidade, totalizava 3.111 casas, distribuídas em 120 quadras e com extensas áreas verdes para aproveitamento futuro (lazer, escolas, postos de saúde, etc.)

Importante registrar que este empreendimento foi construído em um período de crescimento da cidade, com atividade plena da indústria pesqueira e implantação do Distrito Industrial e Superporto, ainda sem os reflexos da crise dos anos 80 .

O último conjunto residencial do tipo COHAB foi implantado em 1985, denominado COHAB IV, localizado distante da zona central, próximo a estrada Roberto Socoowski e contíguo ao Bairro Castelo Branco, totalizando 389 casas. Cabe salientar que com o passar dos anos diminuiu a infraestrutura, a dimensão dos terrenos e a qualidade dos materiais utilizados na construção. Houve a implantação de outros dois grandes loteamentos, um deles com habitação, junto ao entroncamento da RS 734, que dá acesso ao Balneário Cassino, e da BR 392 superando a barreira física representada pela rodovia Rio Grande/Pelotas. (Salvatori, 1988)

O loteamento com habitação, denominado Parque Residencial São Pedro foi construído no início da década de 1980, junto a estrada que leva ao balneário, financiado pela iniciativa privada e destinado a famílias de classe média-baixa, totalizando 1.207 moradias distribuídas em 47 quarteirões.

Entre o Parque Marinha e o Parque São Pedro, bairros de padrão popular, foi projetado um bairro para a classe A, com terrenos de dimensões maiores ( 15 metros por 50 em média), denominado de Jardim do Sol. Este bairro representou uma novidade em relação a ocupação urbana, pois até então as classes mais abastadas viviam nas áreas centrais em função da concentração de serviços. Foram comercializados 460 lotes, distribuídos em 26 quadras em largas avenidas e com toda a infraestrutura básica.

Neste período houve outros loteamentos de menor impacto para a cidade, empreendimentos destinados ao público de baixa renda e financiados pelo poder público estadual e municipal respectivamente, são os bairros Profilurb I, com 333 lotes e Castelo Branco com 1.680 lotes.

Cabe registrar que nas décadas de 1970 e 1980 a Prefeitura Municipal regularizou áreas anteriormente ocupadas, que aparecem nos documentos de aprovação de loteamentos fazendo parecer que eram loteamentos novos, como no caso do Bairro Buchholz. Segundo Martins (2016) esta década reforçou o fim da convivência urbana. A cidade de um lado e as estruturas portuárias e industriais de outro, resultado do planejamento urbano, em função da intervenção estatal federal necessária para a implantação de grandes estruturas industriais.

$\mathrm{Na}$ década de 1990 não houve investimentos indústrias significativos, pelo contrário, o número de firmas diminuiu após o fechamento das indústrias pesqueiras. As políticas de ajuste fiscal da década, segundo Martins C. (2010) atingiram diretamente a estrutura industrial e estatal instalada em Rio Grande, e se em 1990, eram 35.802 empregos formais, em 1998 caiu para 26.968. Entre as políticas de ajuste cita-se: a 
permissão da entrada de pescado sem tarifas aduaneiras que atingiu as indústrias locais; o fechamento da Rede Ferroviária Federal (RFFSA), e da Companhia Rio-Grandense de Telecomunicação (CRT) resultante dos ajustes na estrutura do emprego público.

Nesta década é promulgada a Lei de Modernização dos Portos (Lei 8.630/93) que alterou as relações de trabalho e possibilitou a concorrência entre terminais públicos e privados, gerando redução no número de empregos. O Plano de Demissão Voluntária (PDV) do governo estadual, a crise da indústria pesqueira, o fechamento de duas plantas industriais de fertilizantes e uma de óleo de soja, ocasionaram uma redução estimada de $70 \%$ nos postos de trabalho da indústria local e no complexo portuário. (Domingues, 2009.)

Este período também foi marcado pela inércia de investimentos em habitação para a população de baixa renda, já resultado da extinção do BNH em 1986. O congelamento dos projetos habitacionais juntamente com o desemprego, fez com que boa parte da população que vivia de aluguel não tivesse mais condições para pagar.

Neste contexto muito buscaram ocupar os vazios urbanos existentes surgindo ocupações na Avenida Argentina, na Hidráulica, no terreno da Aliança Bahia (na rua $1^{\circ}$ de Maio, ocupado em 1995), estas áreas situam-se próximas ao centro da cidade e já possuíam infraestrutura. Segundo Rocha e Martins (2010) os ocupantes dos lotes da Hidráulica e Avenida Argentina conseguiram resistir e permanecem até hoje, já os ocupantes do terreno da Aliança da Bahia foram removidos para o bairro Castelo Branco II no ano de 1996.

Neste cenário de ocupações temos $\mathrm{o}$ surgimento do bairro Cidade de Águeda no ano de 1993, contando inicialmente com 108 lotes. Tornou-se um marco da retomada das políticas públicas a partir de 2003 com a construção de loteamentos para moradias populares. Atualmente o bairro conta com um total de 564 lotes ocupados. (Rocha e Martins, 2010).

As mudanças na estrutura produtiva do município foram tão significativas que o início do século XXI Rio Grande passou a figurar como uma área de estagnação econômica. Contrariando as expectativas, a primeira década deste século traria novas perspectivas para Rio Grande. A decisão do Governo Federal de impulsionar e descentralizar a indústria naval, após a descoberta da camada de Pré-Sal na Bacia de Santos, teria importante reflexo na cidade portuária.

O Estado do Rio Grande do Sul entra no segmento da indústria naval através da implantação do Polo Naval e Offshore do Rio Grande, que se consolida em 2006 com o planejamento da construção da Plataforma P-53 para a Petrobrás, oportunizando a dinamização da cidade até então depreciada economicamente (Parfitt; Gallo e Alba, 2019).

A cidade do Rio Grande viveria um novo pulso econômico, a partir da implantação do polo iniciava-se um processo de atração de trabalhadores e de empresas que atuavam nos segmentos da indústria naval. De 1990 a 2010, segundo IBGE, o município do Rio Grande teve um crescimento de $15 \%$ na população urbana e, atualmente, $96 \%$ residem em áreas urbanas. No ano de 2013 foram gerados 19.954 empregos, sendo que os investimentos do polo naval geraram uma oferta total superior a 30.000 empregos diretos e indiretos (Domingues, 2009; Ramos; Martins, 2016).

Em 2007 o governo federal cria o Plano de Aceleração do Crescimento (PAC) com o objetivo de estimular o crescimento econômico através de projetos de infraestrutura. Além de investimentos destinados ao Polo Naval e ao complexo portuário, o município recebeu investimentos para o setor de habitação, tendo dois empreendimentos consolidados. Rio Grande também receberia investimentos em habitação do programa Minha Casa Minha Vida PMCMV, criado em 2009, destinado a famílias de menor renda totalizando oito empreendimentos construídos. Além desses, o convênio da Caixa Econômica Federal com a prefeitura municipal obteve quatro empreendimentos.

Os impactos do setor naval/portuário no mercado imobiliário foram mapeados por Ramos e Martins (2016), considerando somente aqueles empreendimentos que apresentaram localização exata expressa nos documentos de liberação ambiental. Entre 2007 e 2015, o espaço urbano do Rio Grande teve 28 empreendimentos imobiliários consolidados, totalizando 3.068 unidades habitacionais. Cabe ressaltar que os dados referentes as unidades dos Residenciais Senandes e Ongaratto estão fora da abrangência de nosso objeto de estudo.

Dos empreendimentos mapeados pelos autores destacamos um importante empreendimento financiado pelo PAC, denominado: Residencial BGV I, com 220 unidades habitacionais e Residencial BGV II com 70 unidades, localizado na Rua Bento Martins, próximo à Rua Barroso, destinado aos moradores de áreas ocupadas irregularmente próximas ao porto, atingidos pelo plano de expansão portuária. 
Em relação ao PMCMV destacamos três empreendimentos: a construção de 100 casas no Parque São Pedro, entregues em 2011, segundo Pandolfo (2018) essas moradias significaram importante crescimento espacial do bairro; e a construção do Residencial Jockey Club I, Jockey Club II e Jockey Club Master, entregues em 2013, cada um com 200 unidades habitacionais, ao lado do Praça Rio Grande Shopping Center, que representou significativo fator de adensamento populacional do bairro Vila Prado ondes está inserido.

O fomento econômico gerado pela instalação do Polo Naval promoveu a construção de dois shopping centers: o Praça Shopping Rio Grande e o Partage Shopping Rio Grande, ambos com importante influência nos locais em que se consolidaram.

O Praça Shopping Rio Grande localiza-se na Vila Prado, junto as instalações do antigo hipódromo, em uma área total de $125.000 \mathrm{~m}^{2}$, sendo $38.000 \mathrm{~m}^{2}$ de área construída, foi inaugurado em abril de 2014. A proposta inicial do empreendimento era a construção de um complexo que contaria também com um hotel 3 estrelas, um hotel 4 estrelas, 2 torres comerciais e 8 torres residenciais, mas o declínio da economia local em função da decadência do Polo Naval não permitiu a concretização em sua totalidade, permanecendo somente a edificação do shopping.

O Partage Shopping Rio Grande localizase no Parque São Pedro próximo a RS 734, em uma área total de $139.485 \mathrm{~m}^{2}$, teve suas atividades comerciais iniciadas em 05 de novembro de 2015. A área que até meados de 2011 era marcada por pastagens e poderia ser considerada um vazio urbano deu lugar a um centro comercial. Juntamente com o shopping havia a previsão de construção de um condomínio de apartamentos, que até o momento não se concretizou. $O$ empreendimento influenciou a alta dos valores imobiliários do entorno nos primeiros anos de atividade, mas este processo não resistiu a decadência econômica do município (Pandolfo, 2018).

Um empreendimento de grande porte está sendo construído com recursos do Programa Minha Casa Minha Vida Entidades - PMCMV-E, denominado Empreendimento Junção, localizado no bairro de mesmo nome, destinado a pessoas de baixa renda. Serão 1.276 unidades ao todo, sendo 1.120 apartamentos e 156 casas, com média em torno de 6.000 pessoas. O projeto que teve início no segundo semestre de 2016 e tem previsão de entrega para 2019 vem ajudar na redução do déficit habitacional, carência histórica do município.
Cabe ressaltar outro empreendimento PMCMV, situado nas proximidades da FURG, na estrada Roberto Socooswski, no bairro São João. Denominado Residencial Bragança é um projeto com mais de $54.000 \mathrm{~m}^{2}$ de área construída, 28 blocos com 7 andares, totalizando 784 apartamentos, com obras iniciadas em janeiro de 2016 e previsão de entrega para maio de 2019 (Residencial Bragança, 2018)

Segundo a Prefeitura do Rio Grande esta área receberá a construção da nova sede do Foro da Comarca do Rio Grande e o novo prédio do Ministério Público. As autoridades públicas do município demonstram interesse em criar novas centralidades com projetos para a periferia da cidade, junto a estrada Roberto Socoowski, destacando a facilidade de acesso para a Universidade, o Cassino, o Partage Shopping e Pelotas, promovendo a melhoria da infraestrutura, mobilidade e moradia para a população desta zona da cidade.

As políticas públicas quanto a novas áreas de urbanização, consolidam a tendência verificada desde o século XIX de expansão urbana para oeste do centro histórico, atualmente junto as principais vias de acesso e de ligação do município com o balneário e com o restante do Estado.

Na Figura 4 é demonstrada a expansão do núcleo central urbano da cidade do Rio Grande, relacionando com o crescimento populacional. Os dados obtidos sobre a população, segundo IBGE (2018), referem-se à totalidade do município, mas fornecem parâmetros importantes de análise quanto a ocupação da área urbana nos diversos ciclos econômicos que fomentaram seu crescimento.

\section{Conclusão}

$\mathrm{Na}$ análise de 280 anos de ocupação espacial certamente existe complexidades oriundos das relações homem-natureza e dos diversos atores que configuram a história do município do Rio Grande. Além disso, existe a limitação temporal dos registros cartográficos, visto que cada mapa preserva o registro da paisagem construída até a data de sua elaboração. Entretanto, as funções militar, comercial e industrial da cidade favoreceram a elaboração de mapas ao longo do tempo, desde a colonização europeia, até o presente. 


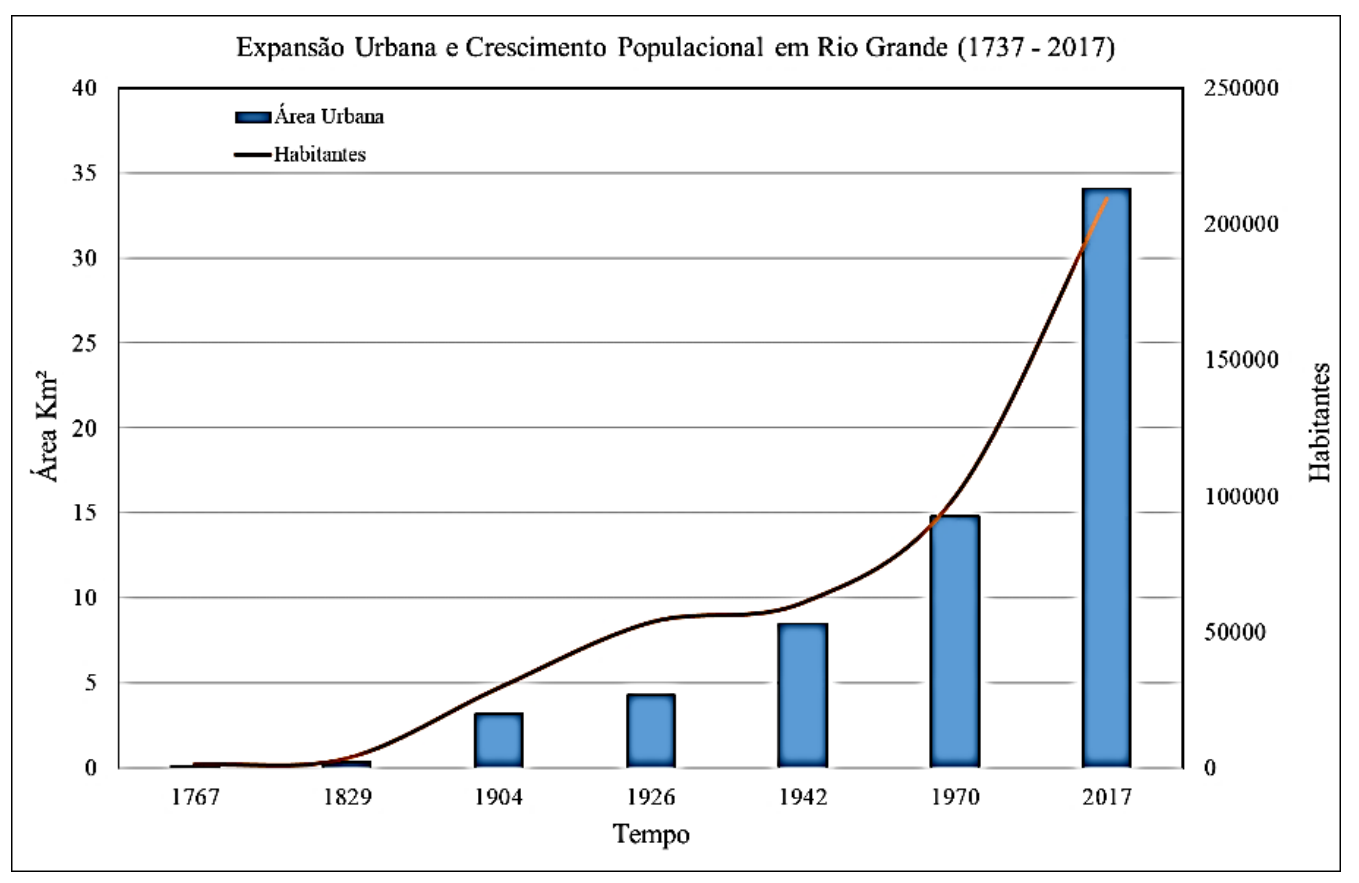

Figura 4. Expansão urbana e crescimento populacional no período de 1767 até 2017. A quantificação da expansão foi obtida na análise dos mapas históricos e os dados de população foram adquiridos em Torres, 2015, p. 76.

Os relatos da chegada dos portugueses em 1737 mostram as dificuldades das águas rasas e dos bancos de areias da Barra do Rio Grande de São Pedro ao desembarque, e o terreno inóspito do pontal formado por dunas, banhados, lagoas e marismas. Mas Rio Grande foi um ponto estratégico para ocupação militar dentro de um momento geopolítico de enfrentamento entre Portugal e Espanha. Esta visão militar surge clara no primeiro mapa de 1737 de José da Silva Paes onde é demonstra a fisiografia da região, a localização do porto e o desenho da fortificação do estreito.

A costa arenosa e com ventos constantes, aliada a falta de materiais duráveis para construção, tornou a ocupação uma tarefa desafiadora. Desde o início do povoamento Rio Grande precisou adaptar-se à natureza do pontal, para tornar-se o primeiro referencial urbano luso-brasileiro nas terras meridionais do Brasil.

O nascimento da economia da Capitania do Rio Grande de São Pedro, nas últimas décadas do século XVIII, assistiu ao protagonismo do porto marítimo do Rio Grande. Essa função essencial no comércio e escoamento de produtos foi determinante para o considerável crescimento das próximas décadas. No mapa de 1829 é registrado a expansão urbana da Vila e seus limites pelo sistema ambiental. Registra-se o primeiro aterro em direção ao Canal do Rio Grande, com vistas a melhoria do Porto Velho e o aterro de marismas ao leste para abertura de ruas e edificações.

O mapa de 1904 demonstra uma cidade que prosperou, cresceu em direção ao Canal do Rio Grande com aterros próximo ao Porto Velho e junto a Santa Casa, urbanizou o terreno da Praça Tamandaré e criou ruas ao sul e a oeste. A expansão urbana atingiu a linha de trincheiras e precisou ultrapassá-las, planejou o primeiro loteamento na chamada cidade extramuros e projetou terrenos ao norte do reservatório da Hidráulica, dando início ao crescimento para oeste verificado até os dias de hoje.

Este mapa (1904) é um documento essencial para a análise das mudanças ambientais, pois pela primeira vez se tem uma visão mais completa dos ambientes naturais que formavam o pontal. O documento possibilitou uma visão detalhada da configuração fisiográfica da região leste do centro histórico, com o registro da Lagoa do Ladino, da Ilha do Ladino, das marismas e canais que logo seriam suprimidos.

O mapa de 1926 registra a profunda alteração a leste do pontal com extensa área de aterros para a construção do Porto Novo. Uma nova geomorfologia foi criada, inclusive com aterros longe da área portuária, para construção de moradias. A expansão não se deteve somente a leste, mas a oeste com o bairro ortogonal ao norte da Hidráulica e a edificação da estrutura do Jockey Club. As primeiras décadas do século XX foram representativas em termo de expansão urbana da Cidade do Rio Grande.

O mapa de 1942 mostra a continuidade no padrão de crescimento para oeste do pontal, com o surgimento das vilas, neste período a expansão 
urbana apresentava uma espacialização um tanto dispersa, pois existiam vastas áreas sem ocupação. Houve efetivação de melhoramentos urbanos na área de transportes, estradas, abastecimento, saneamento, fornecimento de energia elétrica e comunicação

A expansão urbana da cidade do Rio Grande no período de 1942 a 1970 é resultado de um grande fluxo de migrantes em decorrência do período de industrialização. As indústrias pesqueiras ocuparam predominantemente as margens da Lagoa dos Patos, ao norte do pontal. Ao mesmo tempo, a Prefeitura Municipal começou a regularizar os terrenos próximos ao porto e a Swift, surgindo loteamentos em toda a cidade, com incidência maior a sudoeste.

A imagem extraída do Google Earth Pro de 2017, mostrando a configuração atual do núcleo urbano central da Cidade do Rio Grande, evidencia as transformações do espaço urbano ao longo do tempo, com diversas funções assumidas pela cidade, desde sua vocação portuária, passando por função comercial, industrial e na última década a de Polo Naval.

Notadamente cada período deixou a sua marca na configuração do espaço urbano com a chegada de milhares de trabalhadores e a necessidade de adequar o gerenciamento da vida urbana. $\mathrm{O}$ crescimento e estagnação acompanharam esses processos pois cada um deles teve seu apogeu e queda, não gerando riqueza suficiente para que os habitantes usufruíssem de uma melhor qualidade de vida. Cabe ressaltar que na última década, os programas de habitação favoreceram o adensamento urbano e não a expansão como registrado no século passado.

A necessidade de "criar terreno" para a expansão urbana promoveu profundas alterações na fisiografia do pontal. O crescimento ordenado e não ordenado gerou poluição, desmatamento, assoreamentos de arroios, destruição de ecossistemas e utilização de áreas preservadas para usos urbanos, gerando diversos desafios ambientais que Rio Grande precisa enfrentar na busca de um equilíbrio entre os interesses econômicos e ambientais.

\section{Agradecimentos}

O presente trabalho foi realizado com apoio da Coordenação de Aperfeiçoamento de Pessoal de Nível Superior - Brasil (CAPES) Código de Financiamento 001.

\section{Referências}

Biblioteca Nacional do Rio de Janeiro, 2019. A Representação cartográfica no Brasil Colonial.

Disponível:http://bndigital.bn.gov.br/proje tos/cartografia/cart_colonial.html.Acesso: 12 fev. 2019.

Biblioteca RioGrandense. 2018. Arquivos de mapas históricos. Rio Grande. RS.

Cintra, J. P., 2015. Técnicas de leitura de mapas históricos: uma proposta. Revista Brasileira de Cartografia [online], $n^{\circ}$ 67/4 773-786. Disponível: http://www.lsie.unb.br/rbc/index.php/rbc/ article/view/1260/825. Acesso: 12 jan. 2019.

Copstein, R., 1982. Evolução urbana de Rio Grande. Porto Alegre, Revista do Instituto Histórico e Geográfico do Rio Grande do Sul, v. 122, 43-68.

Cunha, R. B.; Ruckert, A. 2019. Ações de atores territoriais: A construção do Porto de Rio Grande- RS, Brasil, como um nó estratégico no território do sul do Brasil. Para onde? Universidade Federal do Rio Grande do Sul, v. 11, 45-54.

Diedrich, M. H.; Machado, N. T. G. 2020. Toponímia: cultura e patrimônio do Rio Grande do Sul. Caderno Prudentino de Geografia, v. 1, 98-117.

Domingues, M. V. R., 2009. Desenvolvimento e Consolidação do Polo Naval e Off Shore de Rio Grande. Secretaria do Desenvolvimento e dos Assuntos Internacionais (SEDAI), Ed. FURG, Rio Grande.

Dreys, N., 1961. Noticia Descritiva da província do Rio Grande de São Pedro do Sul. Globo, Porto Alegre.

Dumith, R.C., Telles, R.M. e Lucas, L. M., 2008. Modificações geomorfológicas do sítio urbano do Rio Grande (RS), a partir da intensificação do uso e ocupação do solo. Comitê Latino-Americano de Geografia Física [online] 12. Disponível em : http://w3.ufsm.br/vslagf/eixo3.pdf. Acesso: 12 set. 2017.

Figueiredo, C. C. et al., 2013. Análise da evolução urbana da cidade do Rio de Janeiro a partir de mapas históricos. Revista Brasileira de Cartografia [online] 65. Disponível: http://www.lsie.unb.br/rbc/index.php/rbc/ article/view/597. Acesso: 15 out.2017.

IBGE. Instituto Brasileiro de Geografia e Estatística. 
Disponível:https://cidades.ibge.gov.br/bra sil/rs/rio-grande/panorama. Acesso: 24 jun. 2018.

IBGE. Instituto Brasileiro de Geografia e Estatística. Atlas Escolar. Disponível:https://atlasescolar.ibge.gov.b r/conceitos-gerais/historia-dacartografia/a-origem.html. Acesso: 24 jan.2019.

Jornal Rio Grande, 2017. Planta da Cidade do Rio Grande de 1970. Rio Grande. 12 abr. 2017.

Luccok, J., 1935. Aspectos Sul-riograndenses. Trad. Nelson C. de Mello e Souza, Ed. Record, Rio de Janeiro.

Martins, C.A.A., 2010. Morar e habitar em áreas portuárias na cidade do Rio Grande -RS, Brasil. Scripta Nova. Revista Electrónica de Geografía y Ciencias Sociales. Barcelona[online\} 14. Universidad de Barcelona. Disponível: http://www.ub.es/geocrit/sn/sn-331/sn331-30.htm. Acesso: 23 jan. 2018.

Martins, C.A.A., 1997. Nas águas da lagoa há reprodução da vida: pesca artesanal em Rio Grande -RS. Dissertação (Mestrado). São Paulo, USP.

Martins, S. F., 2016. Cidade do Rio Grande: industrialização e urbanidade (1873-1990). $2^{a}$ ed. Revisada e ampliada. Ed. FURG, Rio Grande.

Martins, S. F., 2004. A produção do espaço em uma cidade portuária através dos períodos de industrialização: o caso do município do Rio Grande - RS. Tese (Doutorado). Florianópolis, Universidade Federal de Santa Catarina.

Noguez, E.L.B., 2015. Gênese e transformações do bairro Cidade Nova no município de Rio Grande/RS. Dissertação (Mestrado). Rio Grande, Universidade Federal do Rio Grande -FURG.

Oliveira, C. de., 1993. Curso de Cartografia Moderna. $2^{a}$. ed. IBGE, Rio de Janeiro.

Pandolfo, C. de A. 2018. A produção do espaço urbano e o discurso de uma nova centralidade pelos agentes produtores do espaço: Parque São Pedro, Partage Shopping e o Empreendimento Vivea (Rio Grande -RS). Dissertação (Mestrado). Rio Grande, Universidade Federal do Rio Grande - FURG.

Pandolfo, C. de A. 2018. O Direito à cidade: Uma reflexão teórica sobre a produção urbana no Brasil. In: Evilhane Jum Martins; Francielle Benini Agne Tybusch; Jerônimo Siqueira Tybusch. (Org.). Direito e saber na América Latina. Ithala, Curitiba. pp. 01166.

Parfitt, C. M.;

Pimentel, F., 1944. Aspectos gerais do município do Rio Grande. Rio de Janeiro: IBGE.

Queiroz, M.L.B., 1987. A Vila do Rio Grande de São Pedro (1737-1822). Ed. FURG，Rio Gallo, B. B.; Alba, J. M. F. 2019 Atividade portuária, globalização e crescimento de Rio Grande e São José do Norte - RS Brasil (1990 - 2010). Geografia (Londrina), v. 28, 81-100.Grande.

Ramos, B.R.; Martins, S. F., 2016. Dinâmica socioepacial a partir das transformações econômicas e industriais do setor naval/portuário na cidade do Rio Grande, RS. In: Heidrich, A. L. et al. Estruturas e dinâmicas sócioespaciais urbanas no Rio Grande do Sul: transformações em tempos de globalização (1991/2010). Editora Letra, v. 1, Porto Alegre, 47-67.

UFPEL. Universidade Federal de Pelotas. Agência de Desenvolvimento da Lagoa Mirim (arquivos). Pelotas/RS.

Residencial Bragança. Empreendimentos. Disponível:

http://www.porto5.com.br/lancamentos/19 46/residencialbragan\%C3\%A7http://www .porto5.com.br/lancamentos/1946/residen cial-bragan\%C3\%A7a. Acesso: 03 fev. 2019.

Rocha, W.M.; Martins, C.A.A., 2010. As políticas públicas de moradia: a formação do loteamento Cidade de Águeda no município do Rio Grande - RS. Disponível em:

http://repositorio.furg.br/bitstream/handle/ 1/1102/As\%20pol\%EDticas\%20p\%FAbli cas\%20de\%20moradia\%20a\%20forma\%

E7\%E3o\%20do\%20loteamento\%20Cidad e\%20de\%20\%E0gueda\%20no\%20munic $\%$ EDpio\%20do\%20Rio\%20GrandeRS..pdf?sequence $=1$ Acesso em: 30 jun. 2018.

Sá, S. P., 1993. História topográfica e bélica da nova Colônia do Sacramento do Rio da Prata. Arcano 17, Porto Alegre.

Saint-Hilaire, A., 1987. Viagem ao Rio Grande do Sul. ERUS/Martins Livreiro, Porto Alegre.

Salvatori, E., Habiaga, L. A. G. P., Thormann, M. C. 1989. Crescimento Horizontal da Cidade do Rio Grande. Revista Brasileira de Geografia, v. 51, $27-71$.

Telles, R. M., 2011-2012. Evolução geomorfológica de Rio Grande (RS): um confronto de dois tempos. In: CaderNAU- 
Cadernos do Núcleo de Análises Urbanas, v.5, 4-20.

Torres, L. H. 2006. Os muros da cidade antiga: as trincheiras. Revista do Instituto de Ciências Humanas e da Informação. Universidade Federal do Rio Grande FURG, v. 19, 75-82.

Torres, L. H., 2010. Rio Grande: cartões-postais contam a história. Ed. FURG, Rio Grande.
Torres, L. H., 2015. História do Município do Rio Grande: fundamentos. Pluscom Editora, Rio Grande.

Torres, L. H.,2016. Os leões da Praça Tamandaré: história da Geribanda e do monumento a Bento Gonçalves da Silva. Pluscom Editora, Rio Grande.

Torres, L. H., 2018. Rio Grande: imagens que contam a História. 2a ed., rev. e ampl. Pluscom Editora, Rio Grande. 